\title{
1 Analysis of Classic Tomato Mutants Reveals Influence of 2 Leaf Vein Density on Fruit BRIX
}

5 Zizhang Cheng $^{\mathrm{a}}$, S.D. Rowland ${ }^{\mathrm{b}}$, Karo Czarnecki ${ }^{\mathrm{b}}$, Kristina Zumstein ${ }^{\mathrm{b}}$, Hokuto Nakayama ${ }^{\mathrm{c}}$, and 6 Neelima R. Sinhab

$8 \quad{ }^{a}$ Sichuan Agricultural University, Chengdu, Sichuan, China

$9 \quad{ }^{b}$ Department of Plant Biology, University of California, Davis, Davis, CA 95616

10 ' ${ }^{\mathrm{c}}$ University of Tokyo, Tokyo, Japan

11 ORCID IDs: 0000-0002-6560-0280 (Z.C.); 0000-0002-8633-1710 (S.D.R.); 0000-0001-6245-0558 (K.C.), 0000-

12 0001-9516-8081 (K.Z.); 0000-0002-5724-4861 (H.N.); 0000-0002-1494-7065 (N.R.S.)

\section{Author Contributions}

15 N.R.S. conceived of the research idea, supervised the research, helped to write the manuscript, and agrees to be the 16 author for contact. Z.C. led the research effort, collected and analyzed data, and wrote the initial draft with input 17 from all authors. S.D.R. collected leaf photosynthesis data, helped with field sample collection, gave advice on 18 research and analysis methods, and developed vascular clearing, sugar, and starch extraction protocols. K.C. 19 performed root grafting experiments, gene coexpression network construction, leaf sugar and starch analysis, and led 20 paper editing and data analysis efforts. K.Z. organized the field study and helped with leaf sample collection. H.N. 21 helped with RNA sequencing, field sample collection, and leaf venation analysis.

\section{Corresponding Author}

24 Neelima R. Sinha (nrsinha@ucdavis.edu)

\section{ABSTRACT}

Tomato bipinnate (bip) is a classic leaf mutant, with highly increased leaf complexity resulting from the loss of function of a BEL-LIKE HOMEODAMAIN (BELL) gene. Here, we analyzed several bip mutants and their isogenic wildtype backgrounds for a suite of leaf

30 morphology traits, ranging from leaf complexity, leaflet shape and size, to leaf vascular density

31 to investigate how changes in leaf morphology influence fruit traits. Our analyses showed an

32 unexpected relationship between leaf vein density and fruit sugar levels, where leaf vein density 33 was negatively correlated with fruit BRIX. RNA-Seq analysis suggested variation in Glucose-6- 
phosphate translocator2 (GPT2) gene expression caused correlated changes in leaf vein density and BRIX when bip mutant and wildtype were compared, suggesting that the correlation between leaf vein density and fruit sugar may result from the genes regulating leaf vein development that are also involved in regulating leaf sugar biosynthesis. Our results provide a resource for further exploration of the genetic basis for the complex relationship between fruit quality and leaf traits in natural populations.

\section{INTRODUCTION}

Tomato (Solanum lycopersicum) is one of the highest-value and most extensively used vegetable crops worldwide. However, to meet increasing demand, modern tomato cultivars have been selected for qualities such as size and firmness instead of taste (Beullens et al., 2008; Wang and Seymour, 2017). Consequently, most of modern commercial varieties have lost their flavor and are often tasteless (Klee and Tieman, 2013; Tieman et al., 2017).

Flavor of fruit is the sum of interactions between taste and aroma, whereas sugars and acids are the two of primarily components to activate taste receptors and aroma components such as volatile compounds activate olfactory receptors (Malundo et al., 1996; Baldwin et al., 2008; Tieman et al., 2012). Though the relative contribution of taste and aroma to fruit flavor has not been clearly defined (Malundo et al., 1996), plenty of studies have shown the importance of sugars and acids in determining fresh fruit flavor (Malundo et al., 1996; Baldwin et al., 2008; Beckles et al., 2012). For tomato, the levels of sugars and acids not only contribute to tomato taste (sweetness and sourness), but also are major factors affecting tomato overall flavor intensity (Allen Stevens, 1979; Jones and Scott, 1984), and increasing sugar content of the fruit will enhance tomato flavor (Malundo et al., 1996; Tieman et al., 2017). Recent studies have shown that fruit sugar accumulation in modern tomato is two to three-fold less than that in wild species (Beckles et al., 2012), which can account for the decline in flavor quality of tomato fruit.

Fruits are the primary photosynthetic sinks and over $80 \%$ of sugars in the fruit are

60 produced in the leaf through photosynthesis and subsequently translocated through the phloem

61 (Cocaliadis et al., 2014). Therefore, factors involved in regulating leaf photosynthesis, as well as

62 sugar biosynthesis and sugar transport would have an effect on sugar levels in fruit. Leaves are

63 the principle site of plant photosynthesis and leaf traits (e.g. shape and size) directly impact the 64 efficiency of light capture and photosynthetic carbon fixation (Smith et al., 1997; Sarlikioti et al., 
2011). Thus, changes in leaf traits could have an effect on fruit yield and quality. Studies evaluating the influence of leaf area on tomato yield have shown high leaf area index (LAI) can lead to an increase in tomato yield as a result of better light interception (Heuvelink et al., 2005). Recently, leaf shape was shown to be strongly correlated with fruit sugar levels in tomato, with rounder and more circular leaves having higher sugar content in their fruit (Chitwood et al., 2013; Rowland et al., 2019). These studies focused on the influence of leaf morphology on fruit sugar level, and revealed important correlations between leaf shape and fruit sugar accumulation. However, how leaf shape contributes to sugar accumulation in fruit is not yet known (Malundo et al., 1996; Chitwood et al., 2013). The impact of leaf traits such as leaf complexity and leaf veins (as the direct conduit of sugar transport) on fruit sugar levels is currently uninvestigated.

Tomato bipinnate (bip) is a classic leaf mutant, with highly increased leaf complexity

(Fig. 1A) resulting from the loss of function of a BEL-LIKE HOMEODAMAIN (BELL) gene (Kimura et al., 2008) called BIPINNATE (BIP, Solyc02g089940) (Fig. 1B), and provides ideal material to investigate the influence of leaf traits on fruit sugars. To investigate the links between leaf complexity and fruit sugar accumulation, we performed an analysis of leaflet shape, leaf complexity, vein density, yield, and fruit BRIX on bip mutants (bip2 and bip0663) and their isogenic backgrounds (M82 and Lukullus, respectively). Results suggested that leaf vein density, and not leaf complexity, was highly correlated to fruit BRIX in bip mutants. RNA-Seq analysis of gene expression in the vegetative apices and leaves of bip mutants and wildtypes shows an association between the expression of genes regulating leaf vein development and carbohydrate metabolism and transport, suggesting that alteration in leaf vein development would also modulate processing of carbohydrate metabolism and transport which, in turn, affects the accumulation of fruit sugar. Our analysis offers insight into how leaf morphology may influence fruit sugar and provides a new direction to improve tomato fruit sugar content.

\section{RESULTS}

\section{Leaf Complexity and Fruit BRIX of bip Mutants and Wildtype}

To investigate whether changes of leaf complexity caused by mutations at the BIP gene

93 have an effect on fruit BRIX, we measured leaf complexity and fruit BRIX of bip0663 mutants

94 and the corresponding isogenic cultivar, Lukullus. Leaf complexity and fruit BRIX of mutants

95 bip0663 were both significantly increased in comparison to that of Lukullus (Fig.2A and 2B). 
96 However, another bip mutant, bip2, had significantly increased leaf complexity (Fig.2A), but

97 fruit BRIX similar to its isogenic cultivar, M82 (Fig.2B). These results indicate changes in leaf

98 complexity are not directly correlated fruit BRIX. Additionally, fruit BRIX of both bip0663 and

99 Lukullus were respectively higher than that of bip2 and M82. Fruit yield was also measured,

100 since yield has an impact on fruit BRIX (with a general negative correlation between yield and

101 BRIX) (Caliman et al., 2007). We saw fruit yield in bip0663 similar to Lukullus, while bip2 fruit

102 yield was lower than M82, suggesting that the difference between bip0663 and Lukullus BRIX

103 was not directly related to variation in yield. Similar to fruit BRIX, fruit yield of bip0663 and

104 Lukullus was also significantly higher than that of bip2 and M82. This result was confirmed by

105 sampling across two seasons (2016 and 2017) in the field and in greenhouse experiments (Figure

106 S2).

107

\section{Influence of Leaf Traits on fruit BRIX between bip0663 and Lukullus}

To validate whether changes in leaf traits contributed to the changes in fruit BRIX between bip0663 and Lukullus, we performed a grafting assay where the Lukullus and bip0663

111 separately functioned as reciprocal scion and rootstock. During flowering and fruiting stage,

112 leaves on scion and flowers and fruits on rootstock were completely removed. Thus, the

113 flowering and fruiting of scion were driven by photosynthate transfer only from the leaves on the

114 rootstock portion. In the control group, the Lukullus and bip0663 were self-grafted and generated

115 a fruit BRIX (Fig.3A) that resemble their nongrafted lines (Fig.2B). In treatment group, when

116 bip0663 served as the rootstock for Lukullus (scion/rootstock: Lukullus/bip0663), fruit BRIX of

117 Lukullus was significantly increased compared with its self-grafted line (Lukullus/Lukullus), and

118 when Lukullus served as the rootstock for bip0663 (bip0663/Lukullus), fruit BRIX of bip0663

119 was decreased compared with to its self-grafted line (bip0663/bip0663) (Fig.3A). In addition,

120 measurements of fruit yield show that there was no significant difference in fruit yield between

121 control and treatment group (Fig.3B). These results indicate changes in fruit BRIX between

122 bip0663 and Lukullus were either caused by photosynthate quantities or efflux from leaves or 123 changes in root sink strength.

124 It was possible that the grafts containing Lukullus rootstock could have reduced fruit sugar 125 due to increased sink strength of Lukullus roots. To determine if differences in root sink strength 126 could have contributed to the differences in fruit BRIX, a second grafting assay was performed 
127 in which the roots of each genotype were reciprocally grafted. Root grafts with bip0663 scion

128 had the same high fruit BRIX and yield, regardless of the root genotype. Similarly, root grafts

129 with Lukullus scion showed lower fruit BRIX and yield, regardless of the root genotype (Fig.4).

130 There were no significant differences in fruit BRIX or yield when comparing bip0663/bip0663 to

131 bip0663/Lukullus or Lukullus/Lukullus to Lukullus/bip0663 grafts (Fig.4). This supports the

132 hypothesis that the presence of bip0663 source leaves led to increased fruit BRIX of the grafts.

133 To further examine the differences between bip0663 and Lukullus source leaves, the

134 sugar and starch content of leaves was measured at dusk. The leaves of bip0663 had less sugar

$135(\mathrm{p}=0.0939)$ and less starch $(\mathrm{p}=0.0074)$ than the leaves of Lukullus (Fig.5). This suggests that

136 bip0663 source leaves export photosynthate more efficiently than those of Lukullus.

137 Leaf shape analysis of bip mutants and wildtype

138 Since the grafting experiment indicated that changes in leaf features could drive changes

139 in fruit BRIX, and recent studies in an introgression population and a selected group of heirloom

140 tomato varieties show leaf shape is strongly correlated with fruit BRIX and sugar accumulation

141 (Chitwood et al., 2013), we did leaf shape analysis on bip mutants and their isogenic wildtype

142 cultivar to see whether changes in fruit BRIX between these genotypes were also correlated with

143 variation in leaf shape. Results from PCA analysis of a total of 1500 primary leaflets showed that

144 PC1 contributes $65 \%$ of all variation of leaflet shape, and is strongly correlated with leaflet area

145 (or size) $\left(\mathrm{R}^{2}=0.98\right)$, suggesting leaf size was the largest source of variation among leaflets of the

1464 genotypes. PC4 contributes $3.8 \%$ of all variation and is correlation with aspect ratio with an $\mathrm{R}^{2}$

147 of 0.6 (Fig.6A and 6B). PC2, PC3 and PC5 were not correlated with any traditional shape

148 measures, and may describe the overall variation in leaf symmetry (Chitwood et al., 2013;

149 Rowland et al., 2019). Fig.6C show results of traditional leaf shape measurements. Both bip2

150 and bip0663 shows a similar change in leaf shape compared with their corresponding isogenic

151 wildtype backgrounds: leaflet area and solidity decreased, and leaflet aspect ratio and circularity

152 increased. These results indicate that mutations in the BIP gene not only regulate leaf

153 complexity, but also alter leaflet shape. Lukullus and bip0663 displayed leaflet aspect ratio and

154 circularity significantly higher than that of bip2 and M82. Compared to both isogenic wild

155 genotypes, both bip mutants displayed rounder leaflets, with significantly higher aspect ratios

156 and circularity measures.

157 Leaf photosynthesis of bip mutants and wildtype 
In order to determine leaflet contribution to fruit sugar, we performed leaflet $A$, gst, PARi, and ФPSII measurements on bip mutants and their corresponding isogenic wildtype cultivars during fruiting stage (week 17-21). Correlations between $A$ and gst (Fig.7A), were similar between bip2, bip0663, and their corresponding wildtype cultivars, with photosynthesis reaching a maximum rate between 0.6 to 0.8 gst. All genotypes reached a PARi of greater than $1100 \mu \mathrm{mol} \mathrm{m} \mathrm{m}^{-2} \mathrm{~s}^{-1}$ over the growing season. Due to differences in determinacy between the cultivars, bip2 and M82 reached this peak 1 2 weeks earlier than bip0663 and Lukullus (Fig.7B). Corresponding to increasing PARi with age, ФPSII had an overall downward trend across the whole fruiting season in all genotypes (Fig.7C). Across the whole season, average

167 photosynthetic rates of bip2 and M82 were higher than those of bip0663 and Lukullus (Fig.7D).

\section{Leaf Vascular Patterning of bip Mutants and Wildtype}

Generally, carbon-compounds (such as sugar) required for fruit development and ripening are primarily synthesized in the leaf and then transported to fruit by phloem (Cocaliadis et al., 2014). Therefore, we determined the leaf vascular density of each genotype (Fig.8A and

172 Fig.8B). While the leaf vascular density of bip0663 was significantly reduced compared with

173 Lukullus, the leaf vascular density of bip2 was the same as M82. In addition, overall leaf

174 vascular density of bip0663 and Lukullus both was lower than that of bip2 and M82. Given that 175 changes in leaf vascular density roughly corresponded with the difference in fruit BRIX, we 176 performed a correlation analysis between leaf vascular density and fruit BRIX in all bip mutants 177 and isogenic wildtype cultivars (Fig.8C), A negative correlation with $R^{2}=0.844$ and $p$ 178 value $<2.2 \mathrm{e}-16$ was detected (Fig.8C). This suggest fruit BRIX is tightly and significantly 179 negatively correlated with leaf vascular density.

\section{Fruit BRIX of bip3 and Genotypes with Altered Leaf Vascular Density}

To further confirm the correlation between leaf vascular density and fruit BRIX, we measured the leaf vascular density and fruit BRIX of several other tomato varieties (Fig.9). A

183 mutant phenotype with high fruit BRIX, was found and identified in a mutagenized M82 line,

184 and had rounder fruits, hence we called it M82 "Round" Morph (MRM). MRM had low leaf 185 complexity and big leaflets similar to M82, but with fruit BRIX and yield both significantly

186 higher than M82 (Fig.9A). Genotyping results show that the BIP gene sequence in this line is 187 identical to that in M82. Leaf vascular density analysis of MRM identified extremely reduced 188 vascular density compared to M82 (Fig.9A and 9B). bip3 is another bip mutant in the isogenic 
M82 background but with a similar leaf vein density as M82. Silvery Fir Tree (SiFT, an Heirloom tomato) and $s f^{w l}$ (solanifolia, woxl gene mutant) (Burko and Ori, 2013) both had a low leaf vein density (Fig.9A and Fig.8B). The leaf vein density of MRM, SiFT and $s f^{w l}$ was significantly lower than that of bip3 and M82, while the fruit BRIX was significantly higher than bip3 and M82 (Fig.9B and C). There was a high correlation $\left(\mathrm{R}^{2}=0.855\right.$, p-value=2.2e-16)

194 between leaf vein density and fruit BRIX, further indicating a connection between these two traits (Fig.9D).

\section{Differential Gene Expression}

To understand global transcriptional alterations between high and low BRIX phenotypes and their possible links to leaf vascular density, we performed RNA-seq analysis on leaves of bip0663, Lukullus, M82, and bip2. RNA was extracted at three developmental stages (SAM, young leaf and mature leaf) during fruiting stage (17 weeks from germination).

Differentially expressed genes were defined using ANOVA-like test with $|\log F C|>1$ and FDR $<0.05$. A total of 750 DEGs were obtained between high BRIX genotypes (HB, with low leaf vein density, included bip0663 and Lukullus) and low BRIX genotypes (LB, with high leaf vein density, included bip2 and M82) across three stages. Further, 205 genes were defined to be differentially expressed between bip0663 and Lukullus, and 602 genes were defined to be differentially expressed between HB and LB. We found that 57 genes were shared between these two sets of DEGs (Fig.10A, Table S1). These 57 DEGs were overrepresented in many GOslim categories including cellular process, response to stress, metabolic process, and carbohydrate metabolic process (Table S2).

212 function across plant species, and this is particularly true of genes relating to leaf veins and leaf 213 development (Townsley and Sinha, 2012). Therefore, to narrow down target genes that may be 214 causal for leaf vascular density alterations, we focused on literature curated genes that are

215 already known to regulate leaf vein development in the model species Arabidopsis thaliana 216 (Wenzel et al., 2008; Paul et al., 2013, Parsons-Wingerter et al., 2014). Tomato genes that are 217 orthologous to literature curated genes in Arabidopsis thaliana were generated and named LCV 218 (the literature-curated vascular related genes, Table S3). Interestingly, a shared LCV gene 219 Solyc05g045670（GLUCOSE-6-PHOSPHATE/PHOSPHATE TRANSLOCATOR 2, GPT2） was 
detected in both sets of DEGs (Fig.10A). In SAM and YL, expression of GPT2 were down regulated in both bip0663 and Lukullus compared to other genotypes, and the expression of GPT2 in bip0663 was down regulated relative to Lukullus (Fig.10B). Another genotype identified to have low vascular density and high fruit BRIX, SiFT (Fig. 9A and B), also has down regulated GPT2 expression compared to M82 in P4 leaf primordia (Figure S3) (Nakayama et al., 2020). Solanum pennellii, a wild relative of tomato, with high fruit BRIX, has lower expression of GPT2 in leaves compared to M82 (Koenig et al., 2013). Analysis of its promoter sequence compared to M82 shows SNPs in several putative cis-regulatory elements identified by NSITE-PL (Shahmuradov et al., 2015), including the transcription factor binding sites for HVH21 and GT1 (LRE), and the G-box binding site (Figure S4) (Krusell et al., 1997; Hiratsuka et al., 1997; Ezer et al., 2017).

\section{Co-expression analysis of differential expressed genes}

To detect changes in the patterns of expression of the DEGs between phenotypes with different fruit BRIX, we performed DiffCorr analysis (Fukushima, 2013; Ichihashi et al., 2014) on all detected DEGs. DiffCorr networks were separately constructed on all DEGs between bip0633 and Lukullus comparison (bipvsLu Diffcorr network, Figure S5A) and also between HB and LB comparisons (HvsL Diffcorr network, Figure S5B) with cutoff adjusted pvalue $<0.05$. In these DiffCorr networks nodes with more connected edges represent genes which have the most differential co-expressions between the two compared co-expression networks. Of the top 20 ranked Diffcorr genes, 11 genes were shared and highly differentially co-expressed between bipvsLu and HvsL Diffcorr networks (Figure S5 and Table S4). The expression patterns of these genes were highly different between bip0663 and Lukullus, and also between HB and LB comparisons. Six of these 11 genes were reported to be involved in regulating cellular processes, cell walls, leaf vein development or sugar metabolism. During leaf development, LTP4 (Non-specific lipid-transfer protein, Solyc08g067500, leaf vascular development related), AHL3 (AT hook motif DNA-binding family protein, Solyc03g007150, leaf vascular development related) and FUT11 (Alpha 1,3 fucosyltransferase, Solyc01g108110, cell, cell wall, and leaf vascular development related) were all down regulated in bip0663 and Lukullus, in young leaves and mature leaves compared with bip2 and M82 (Wenzel et al., 2008; Zhou et al., 2013; Bakker et al., 2001). PGL1 (6-phosphogluconolactonase, Solyc01g010250, cell, cell wall, and leaf vascular development related) was up regulated in bip0663 and Lukullus 
251 in ML (Figure S6). Thus, these genes might play an important role in regulating fruit BRIX and

252 leaf vascular density between bip0663, Lukullus, bip2, and M82.

253 In addition, many DEGs detected between the HB and LB groups were involved in regulating

254 both development and carbohydrate metabolism (Table S5). We therefore hypothesize that these

255 genes might be co-expressed during leaf vascular development and involved in regulating leaf

256 sugar metabolism either directly or indirectly through vascular transport processes. To validate

257 this hypothesis, we performed correlation analysis and constructed a gene coexpression network

258 across all genotypes using DEGs enriched in "transcription and development" and "carbohydrate

259 and biosynthesis" related GO terms. Correlation analysis showed most of "transcription and

260 development" related DEGs and "carbohydrate and biosynthesis"- related genes are highly

261 correlated, whereas GPT2 was shown to be positively correlated with many genes related to

262 carbohydrate and biosynthetic process (Fig.10C and Table S6, Pearson correlation with BH

263 adjusted p value<0.05), such as Solyc01g074030 (Beta-glucosidase gene). Interestingly, LTP4

264 showed significantly positive correlation with GPT2. In the Co-expression network, community

265 C3 shows significant enrichment of the shared top ranked DiffCorr genes (including AHL3,

266 PGL1, XTH5, GAE4 and FUT11) listed in Table S5 and is connected to other two communities

267 (C1 and $C 2$ ), which compose a core network (with hub genes with >100 edges). $C 1$ was enriched

268 for genes related to transcription initiation and cell fate specification GO terms, and C2

269 contained genes involved in glucose metabolic process, carbohydrate biosynthetic process, plant

270 organ development, hormone-mediated signaling pathway and shoot system development (Table

271 S7). GPT2 can be found on the border of the core network, within $C 1$ and co-expressed with

272 several genes with hubs $>50$, revealing it might be an important gene that connects leaf vein

273 development and carbohydrate biosynthetic processes together. $C 3$ contained genes involved in

274 glucose-6-phosphate metabolic process, and C5 was enriched for genes involved in cellular

275 carbohydrate biosynthetic processes.

277 DISCUSSION

278 Since sugars synthesized in leaves are the primary source of energy for fruit development 279 and ripening (Cocaliadis et al., 2014), we and others have investigated the link between leaf and 280 fruit. Previous studies have shown leaf traits, such as leaf shape and size are strongly correlated 281 with fruit quality and yield (Chitwood et al., 2013; Rowland et al., 2019, Gupta et al. 2020). In 
282 this study, we used grafting experiments to analyze the influence of leaf traits on fruit sugar

283 level. Our results show that changes in leaves can cause variation in fruit BRIX. Leaf shape

284 analysis showed that both bip mutants had rounder leaflets, with significantly higher aspect ratios

285 and circularity measures, compared to both isogenic cultivars. This suggests bip mutations

286 caused not only high leaf complexity but also rounder leaves. Results also show that leaflet

287 roundness of bip0663 and Lukullus (HB genotypes) was significantly higher than bip2 and M82

288 (LB genotypes). These results agree with previous research that showed tomato with rounder and

289 more circular leaves tend to have the highest sugar content in their fruit (Chitwood et al., 2013;

290 Rowland et al., 2019). Although bip2 has rounder leaves than M82 it does not have measurably

291 higher fruit BRIX (Fig. 2B), suggesting that the roundness caused by the bip mutation does not,

292 by itself, lead to increased BRIX.

293 A previous study (Chitwood et al., 2013) suggested the correlation between leaf shapes

294 and fruit sugar content may be due to the impact of leaf shape on photosynthetic capacity.

295 However, we found that across the whole season, average photosynthetic rates of bip2 and M82

296 (LB genotypes) were higher than those of bip0663 and Lukullus, perhaps resulting from high

297 vein density (vein length per unit area) in the LB genotypes (Sack and Scoffoni, 2013). Thus, the

298 variation in fruit BRIX between these genotypes was likely due to aspects other than leaf

299 photosynthesis. In addition, while mutations in the BIP gene cause increased leaf complexity,

300 only bip0663 has increased fruit BRIX compared with Lukullus. This suggests that leaf

301 complexity is not the cause of changes in fruit BRIX between bip0663 and Lukullus. This is

302 consistent with the results from path modeling connections between leaf traits and fruit BRIX in

303 multiple heirloom cultivars (Rowland et al., 2019). The same path modeling also indicated that

304 photosynthesis was not a major contributor to fruit BRIX (Rowland et. al., 2019).

In leaves, sugars synthesized through photosynthesis are first loaded into leaf veins and then transported out of the leaves to the rest of the plant sinks, such as fruit. Thus, leaf veins also

307 play an important role in fruit sugar accumulation by contributing to transport of carbohydrates

308 (Cataldo, 1974; Haritatos et al., 2000; Sack and Scoffoni, 2013). Theoretically, higher leaf vein

309 density will increase the contact between vascular and photosynthetic tissues and lower the

310 distance of photosynthate transportation (Adams et al., 2007; Sack and Scoffoni, 2013). Several

311 studies have shown high leaf vein density can not only enable higher $K_{\text {leaf }}$ (leaf hydraulic

312 conductance) and higher rates of gas exchange per leaf area (Sack and Frole, 2006; Boyce et al., 
313 2009; Brodribb et al., 2010), but also can improve phloem loading (Russin and Evert, 1984).

314 Based on these studies, with all else being equal, plants with high leaf vein density should have

315 higher fruit sugar levels. However, in this study leaf vein density was found to be negatively

316 correlated with fruit BRIX in bip mutants and their corresponding isogenic cultivars. This may

317 be caused by the following factors: Leaves with low leaf vein density can enhance mesophyll

318 light capture in shade and result in increased photosynthate (Brodribb et al. 2007; Zhu et al.,

319 2012; Sack and Scoffoni, 2013). Additionally, many free-ending veins were observed in bip0663

320 and Lukullus leaves (Fig.9), which can promote sugar export (Adams et al., 2007).

321 Leaf veins, similar to leaf shapes, also have a remarkable diversity in architecture within

322 and across species. Numerous studies on mutant phenotypes have shown auxin signaling 323 networks play an important role in patterning leaf vasculature. Polar auxin transport (PAT), as a 324 positional cue, determines the sites of vascular cell differentiation, and inhibition of auxin 325 transport can lead to excessive leaf vein growth in Arabidopsis (Enrico et al., 2006). Since auxin 326 also patterns blade outgrowth, leaf morphogenesis and vascular pattern formation can be coupled 327 (Koenig et al.,2009). Genetic and molecular studies have identified many important genes that 328 are involved in regulating vascular pattern formation that are related to auxin transport or 329 biosynthesis (Miyashima et al., 2013; Biedroń and Banasiak, 2018). For example, 330 MONOPTEROS/AUXIN RESPONSE FACTOR 5 (MP/ARF5) and TARGET OF MONOPTEROS 3315 (TMO5) are essential for provascular establishment (Han et al., 2018), AT HOMEOBOX 8 332 (ATHB8) defines preprocambial cell state that is a prelude to vein formation, and ACAULIS5 333 (ACL5) and BUSHY AND DWARF 2 (BUD2), which regulate polyamine synthesis, can inhibit 334 auxin-induced xylem differentiation (Baima et al., 2014), while PHLOEM INTERCALATED 335 WITH XYLEM (PXY) and CLAVATA 3/ESR-RELATED $41 / 44$ (CLE41/44) regulate vascular 336 organization (Etchells and Turner, 2010). Moreover, few genes such as VASCULAR-RELATED 337 NAC-DOMAIN 6/7 (VND6/7), NAC SECONDARY WALL THICKENING PROMOTING 338 FACTOR 1/2 (NST1/2) and ALTERED PHLOEM DEVELOPMENT (APL) are also reported to be 339 related to leaf vascular patterning though regulation of phloem or xylem differentiation (Bonke 340 et al., 2003; Mitsuda et al., 2007; Yamaguchi et al., 2010). In addition, using auxin transport 341 inhibitor (NPA) induced vascular overgrowth, Wenzel and coworkers (Wenzel et al., 2008) 342 identified many vascular related genes that were previously not known to have a role in vascular 343 differentiation in Arabidopsis. These include At1g61800 (GLUCOSE-6-PHOSPHATE/ 
345 2C), and At5g17220 (TRANSPARENT TESTA 19, TT19). These genes had vascular-related expression in transgenic Arabidopsis plants and were notably up-regulated in tissue with vascular overgrowth. In our study, GPT2 (Solyc05g04567, a homolog of At1g61800) was significantly down regulated in low leaf vein density genotypes such as bip0663 and Lukullus, suggesting correlation between leaf vein density and expression of GPT2. Recent studies have shown that GPT2 functions in promoting cell proliferation, which would be one way to link GPT2 with leaf development and vascular patterning. Mutants in gpt2 may have accelerated chloroplast differentiation (Van Dingenen et al., 2016). GPT2 is also involved in starch biosynthesis (Bakker et al., 2001; Dyson et al., 2015). In leaves, GPT2 is responsible for transporting of Glucose-6phosphate (G6P) into plastids where G6P can be used as a carbon source for starch biosynthesis. Therefore, down regulation of GPT2 might decrease transport of glucose into plastids and increase transport of glucose out of the leaf in bip0663 and Lukullus compared with bip2 and M82. Our study showed decreased leaf starch and sugar in bip0063 when compared to Lukullus, which may also be indicative of increased export of sugars from the leaf. sugar content. The first is the purely developmental link between the leaves and the fruit. Studies 361 have shown similarity in morphology (such as size, aspect ratio, etc.) between leaves and fruits 362 (Xiao et al., 2008; Chitwood et al., 2013). This is borne out by the fact that the morphological 363 development of fruits and leaves is regulated by a similar gene regulatory network (Barkoulas et 364 al., 2008). The second is that either genetic changes in overall metabolism alter leaf development or changes in carbon metabolism induce morphological changes in leaves (Hackel et al., 2006; Lawson et al., 2006; Raines and Paul, 2006). For example, ARF4 not only regulates the

367 morphology of leaves and fruits (Yifhar et al., 2012), the accumulation of chloroplasts and the 368 greening of fruits (Jones et al., 2002), but was also recently shown to have influence on fruit 369 sugar levels (Sagar et al., 2013). Because GPT2 has been shown to regulate cell proliferation and 370 is also involved in starch biosynthesis, it could be a common regulator for leaf vein density and 371 carbon allocation. In addition, our analyses show that DEGs enriched in "transcription and 372 development" - GO terms were highly correlated with those enriched in "carbohydrate and 373 biosynthetic"- GO terms. In our gene co-expression network, GPT2 was in the core network 374 involved in biosynthetic and development process and co-expressed with several highly 
connected genes (hubs >50), suggesting that it might be an important and conserved gene that connects leaf vein development and carbohydrate biosynthetic process.

\section{METHODS}

\section{Plant Materials}

The classic bip mutants used in this study and are bip2 (isogenic cultivar: M82) and bip0663 (bip accession number LA0663) (isogenic cultivar: Lukullus). M82, bip0663, and Lukullus seeds were obtained from the Tomato Genetics Resource Center (TGRC, http://tgrc.ucdavis.edu/). bip2 (accession number e0652b) was obtained from the saturated mutation library of tomato (Menda et al., 2004).

\section{Seed germination and plant growth Conditions}

Tomato seeds were treated with $50 \%$ bleach for 10 min and rinsed 3-5 times with water, then placed on water dampened Phytatrays (Sigma Aldrich). Seeds were moved to the dark and incubated at room temperature for 3 days, then transferred to a growth chamber set at $25^{\circ} \mathrm{C}$ with 16:8 photoperiod until seedlings had expanded cotyledons (approximately 4-7 days). The seedlings were then transplanted to 72 Seedling Propagation trays and grown in the chamber for 7 days. After that, seedlings were transferred to the greenhouse or grown for 2 weeks and then transplanted to field. The greenhouse plants were watered from the top to encourage hardening. Field plants were watered with furrow irrigation once weekly.

\section{Analysis of leaf complexity and shape}

Mature fully expanded leaves from adult nodes (leaf 5 and above) were used for leaf complexity and shape analysis, and at least five leaves were collected from each plant for analysis. Leaf complexity is defined as the number of all leaflets present on the leaf. For leaf shape analysis, intercalary and secondary/tertiary leaflets were ignored due to their irregular shapes. Leaf shape was analyzed using a method previously described (Ichihashi et al., 2014). After leaf complexity was measured, the leaflet images were used for shape and size analysis. Leaflets were imaged using Epson Perfection V600 Photo scanner (Epson America Inc., CA, USA), and each individual leaflet image was saved as a binary image so that the leaflet was black on a white background. The binary images were then processed in R using MOMOCS 
406 (Bonhomme et al., 2014). After importing and aligning along their axes, leaflet images were then

407 processed using elliptical Fourier (eFourier) analysis based on the number of harmonics 408 calculated from the MOMOCS package (Bonhomme et al., 2014; Rowland et al., 2019).

409 Traditional leaflet shape measures such as leaflet area (size), solidity, circularity, and roundness

410 (aspect ratio) were measured based on figure pixel. PCA analysis was performed on eFourier

411 results and statistical correlations between Principal Components (PCs) and traditional leaflet

412 shape measures were used to determine the leaf characteristics captured by each PC.

\section{Determination of fruit sugar content}

414 To measure the fruit BRIX, approximately nine tomato fruit from each plant were 415 collected and taken to the lab where the juice was collected and BRIX measured using a 416 refractometer (HI 96801 Refractometer, Hanna Instruments Woonsocket, RI).

417 Analysis of leaf vein density

418 For leaf vein analysis, leaf discs with an area of $0.28 \mathrm{~cm}^{2}$ and were collected by a hole 419 puncher from the second lateral primary leaflets of each plant (the sampling sites were located 420 between second-order veins, seen in Figure S1A). Leaf discs were cleared using a modified 421 method from the Ainsworth lab (Bishop et al., 2018; Rowland et al., 2019). Leaf discs were 422 heated in $80 \% \mathrm{EtOH}$ for 20 minutes at $80^{\circ} \mathrm{C}$ and this process repeated twice or until leaf discs 423 turned white. Leaf discs were then placed in $5 \% \mathrm{NaOH}$ and heated to $80^{\circ} \mathrm{C}$ for 5 minutes and 424 were cooled by incubating at room temperature for 10 minutes. After that $\mathrm{NaOH}$ was removed 425 and leaf discs were treated with $50 \%$ bleach for approximately 30 seconds. Bleach treatment was 426 repeated until leaf discs were clear white. Then leaf discs were washed by $\mathrm{ddH}_{2} \mathrm{O}$ and vacuum 427 infiltrated with $50 \%$ glycerol for 20 minutes. Cleared leaf discs were placed on slides and leaf 428 veins of leaf disc were imaged using Eclipse C1 plus microscope (Nikon Instruments Inc., NY, 429 USA) at a fixed magnification (4X). Leaf veins of images were traced and measured by LEAF 430 GUI (Price, 2012), a tool that facilitates improved empirical understanding of leaf veins structure 431 (http://www.leafgui.org). Leaf vein density is measured as leaf vein length per observed leaf 432 area.

\section{Plant photosynthesis}

434 Leaflet $A$ (photosynthesis), gst (stomatal conductance), transpiration, and $\Phi P S I I$ 435 (percentage of photons entering PSII) were measured weekly using the LI-6400 XT Portable 436 Photosynthesis System (LI-COR, NE, USA) from week 10 through week 15, week 17, and week 
18-21(fruiting stage). Before measurements were taken, leaflets used for measuring were equilibrated for 2-3 minutes to stabilize photosynthetic rates (Rowland et al., 2019). The measurements were done on terminal leaflets. Light within the chamber was at $2000 \mu_{\mathrm{mol} \mathrm{m}}^{-2} \mathrm{~s}^{-1}$

PAR, $\mathrm{CO}_{2}$ concentration within the chamber was set at $400 \mu \mathrm{mols} \mathrm{mol}^{-1}$, and air flow volume within chamber was $400 \mu$ mols s${ }^{-1}$. Humidity, leaf, and chamber temperature (not allowed to

442 exceed $36^{\circ} \mathrm{C}$ ) were allowed to adjust to ambient conditions. The amount of intercepted

443 Photosynthetically Active Radiation (PARi) was also measured in four orientations per plant and

444 then the average PARi was calculated (Rowland et al., 2019).

\section{Grafting assay}

446 The grafting assay used self-grafting as controls and reciprocal grafting of the two 447 genotypes. Lukullus (scion) grafted on bip0663 (rootstock), and bip0663 (scion) grafted on 448 Lukullus (stock) at the first internode as the treatments, while Lukullus grafted on Lukullus and 449 bip0663 grafted on bip0663 at the first internode served as controls (experiment setting seen in 450 Figure S1B-D). Thirty-day old plants grown in the chamber were used for grafting. The grafted 451 plants were allowed to recover for about 7 days before being transferred outside into 2-gallon 452 pots. Once the grafts start flowering, leaves from scion and flowers from the stock were 453 continuously removed to ensure that growth of fruit on scion was only driven by root stock 454 leaves as source. The vegetative biomass, leaf shape, leaf complexity and leaf veins (rootstock), 455 fruit yield, and fruit sugar (scion) were measured.

\section{Root Grafts}

For the root grafting control group, bip0663 scions were grafted onto bip0663 rootstocks, 458 and Lukullus scions were grafted onto Lukullus rootstocks. For the treatment groups, bip0663 459 scions were grafted onto Lukullus rootstocks and Lukullus scions were grafted onto bip0663 460 rootstocks. This grafting was done with 30 day-old plants, and the junction for these grafts was 461 in the internode between the cotyledons and first true leaves. These grafted plants were allowed 462 to recover for 2 weeks before being transferred outside into 2-gallon pots. The grafts were 463 allowed to flower and fruit freely and were regularly checked to assure that there were no leaves 464 emerging from the rootstock portion of the grafts. This allowed us to determine if differences in 465 root sink strength could lead to differences in growth of fruit. The yield and fruit sugar were 466 measured.

467 Leaf Sugar and Starch Measurements 
In order to determine the sugar and starch content of bip0663 and Lukullus, leaf discs with an area of $0.28 \mathrm{~cm}^{2}$ and were collected with a hole puncher from the second lateral primary leaflets of each plant (the sampling sites were located between second-order veins, seen in Figure S1A). These samples were taken at dusk and immediately placed into microcentrifuge tubes containing 500ul of $100 \% \mathrm{EtOH}$. Samples were heated at $80^{\circ} \mathrm{C}$ for 20 minutes. Supernatant

473 was immediately removed, stored at $-20^{\circ} \mathrm{C}$, and used for determination of sugar content 474 (including sucrose, glucose, and fructose). Sugar content was determined as previously described 475 (Rowland et al., 2019). Leaf discs were kept for further processing and starch extraction. 476 Residual sugar was removed from leaves by two additional rounds of heating in 500ul 100\% 477 EtOH, discarding the supernatant each time. Leaf discs were resuspended in 500ul 5\% $\mathrm{NaOH}$ 478 and heated to $80^{\circ} \mathrm{C}$ for 20 minutes. Samples were cooled and neutralized with $125 \mathrm{ul} 5 \mathrm{M} \mathrm{HCl}$. 479 The supernatant was removed, and leaf discs were rinsed $2 \mathrm{X}$ with $\mathrm{ddH}_{2} \mathrm{O}$. Discs were 480 resuspended in $500 \mu \mathrm{L} 50 \mathrm{mM}$ Sodium Acetate Buffer and bead beaten by hand for 30 seconds 481 after the addition of a small metal bead. Samples were centrifuged for 1 minute at $13 \mathrm{~K} \mathrm{rpm}$. $25 \mathrm{ul}$ 482 of a starch degradation mixture, containing a final concentration of 1.3U Amyloglucosidase and $483220 \mathrm{U} \alpha$-Amylase, was added. Samples were incubated at RT for 1 hour, followed by $65^{\circ} \mathrm{C}$ for 23 484 hours. Enzymes were deactivated by heating to $80^{\circ} \mathrm{C}$ for 5 minutes. These samples, now 485 containing glucose were quantified using the same protocol as for sugar samples above.

\section{RNA Extraction}

The shoots or leaf primordia were sampled and frozen in liquid nitrogen or stored at $80^{\circ} \mathrm{C}$. About $100 \mathrm{mg}$ tissue was ground using a Bead-Beater (Bio Spec Products Inc., OK, USA) and RNA was then extracted using a published protocol in routine use in the laboratory

490 (Townsley et al., 2015).

\section{$491 \quad$ RNA-seq Library Preparation and Sequencing}

Tissue (e.g. shoot apical meristem, young leaf, and mature leaf) used for RNA-seq 493 libraries for Illumina sequencing were collected using the method previously described 494 (Townsley et al., 2015). RNA-seq libraries were prepared from collected tissues using the BrAD495 seq method (Townsley et al., 2015). Libraries were prepared from 5 replicates of each type of 496 tissue, collected at fruiting stage (week 17). These RNA-seq libraries were sequenced at the 497 Vincent Coates Genomics facility at University of California, Berkeley on a single lane of the 
Illumina Hi-Seq 4000 platform and 50-bp single-end reads were generated. A total of $326 \mathrm{M}$ raw paired-end $100 \mathrm{bp}$ reads were generated, ranging from 5.7 to $16.3 \mathrm{M}$ reads per library.

\section{Preprocessing of Illumina Reads}

Illumina Reads were trimmed and mapped to reference using CLC Genomics Workbench 11 (https://www.qiagenbioinformatics.com/). Low-quality reads with average Phred quality score $<20$ and low-quality bases from 3' end of the reads were trimmed using the Trim tool in CLC Genomics Workbench. The clean reads were aligned to the tomato reference genomic sequence (ITAG 3.0, Solanum lycopersicum Heinz 1706) by using the Large Gap Read Mapping tool in CLC Genomics Workbench, which models the presence of introns in the tomato genome reference sequence, but are expected to be absent from the corresponding transcriptome. We used the Transcript Discovery Plugin in CLC Genomics Workbench to generate a consensus CDS mapping track based on the existing reference genome (ITAG3.2; https://solgenomics.net). The new transcripts tracks were used as reference for subsequent read mapping.

\section{Differential Expression Analysis}

Reads from individual libraries were mapped to the annotated transcripts reference using default parameters in the RNA-seq mapping tool in CLC Genomics Workbench. Then differential expression analysis between bip mutants and wildtype across three tissues was carried out using limma-voom (Law et al., 2014; Costa-Silva et al., 2017). Transcripts with very low estimated counts $(\mathrm{cpm}<2)$ were removed using limma-voom. Genes with $|\log F C|>1$ and FDR $<0.05$ were considered to be differentially expressed genes (DEGs).

\section{Coexpression and DiffCorr network analysis}

DEGs detected between bip0663 and Lukullus, and between low (M82 and bip2) and high (Lukullus and bip0663) BRIX phenotypes were used for constructing gene co-expression networks with the cutoff values for Pearson correlation coefficient (adjusted $\mathrm{P}<1.0 \times 10^{-8}$ ) to capture gene interactions (Chitwood et al., 2013). Networks were constructed using the WGCNA package in $\mathrm{R}$, and network communities were determined by the Fast-Greedy modularity

524 optimization algorithm. Network visualization was done in Cytoscape (Shannon et al., 2003).

525 Gene ontology of network communities was explored using PANTHER GO-Slim (Mi et al., 526 2019).

DiffCorr analysis was performed on all detected DEGs using the DiffCorr Bioconductor package in R (Fukushima, 2013; Ichihashi et al., 2014). In addition, a gene co-expression 
network across bip0663, Lukullus, bip2 and M82 was constructed using DEGs enriched in "transcription and development" and "carbohydrate and biosynthetic"- related GO terms.

\section{GO Enrichment Analysis}

GO enrichment analysis of the differentially expressed genes was performed using the

533 GOSeq Bioconductor package in R (Young et al., 2012). GO analysis for gene co-expression 534 network communities was performed using PANTHER (Thomas et al., 2003; Mi et al., 2019).

\section{DNA extraction and DNA-seq library preparation}

DNA was extracted from 4 week old M82 plants using GeneJET Plant Genomic DNA DNA fragmentation with Covaris E220 (Covaris, Inc. Woburn, MA, USA), the fragmented DNA was end-repaired, A-tailed, and adapter ligated with Y-adapter. Enrichment PCR was then performed with the adapter ligated product as described Townsley et al., 2015. After final library

542 cleanup with AMPure beads (Beckman Coulter, Brea, CA, USA), DNA-Seq libraries were 543 sequenced at Novogene (Novogene Inc. Sacramento, CA, USA)

\section{WGS Mapping and promoter analysis}

Solanum pennellii LA01716 paired-end Illumina reads were acquired from the European

546 Nucleotide Archive (http://www.ebi.ac.uk/ena/; accession number PRJEB5235). S. pennellii and

547 M82 reads were mapped to ITAG 3.0, Solanum lycopersicum Heinz 1706 genome using BWA 548 (Li et al., 2009). Post-processing of alignment was completed with Samtools 549 (https://github.com/samtools/samtools), and VCF files were generated using Bcftools 550 (http://samtools.github.io/bcftools/bcftools.html). Mapping and VCF files were imported into 551 CLC Genomics Workbench 11.0 software for comparison with M82 sequence. A $3 \mathrm{~kb}$ region 552 upstream of GPT2 (Solyc05g045670) was analyzed for promoter motifs using NSITE-PL 553 (Shahmuradov et al., 2015).

\section{Statistical Analysis}

555 Statistical analyses of leaf shape, leaf complexity, and leaf vein density were all 556 performed using JMP (JMP Pro 14.0.0, 2018 SAS Institute Inc.) software. General Linear 557 Regression Model (GLM) and One-Way ANOVA followed by Tukey's-HSD were used to 558 determine statistical significance in measurements. The BRIX and yield measurements from 559 grafts were analyzed using JMP Pro software. Significance was tested using ANOVA and 
560 Tukey's-HSD pairwise comparisons. Leaf sugar and starch data was analyzed using JMP Pro

561 software. Significance was tested using Student's t test.

\section{SUPPLEMENTAL MATERIAL}

Figure S1. Diagram of leaf disc sampling and grafting experiment.

Figure S2. Fruit BRIX and yield of bip mutants.

Figure S3. Normalized expression of GPT2 in M82 and SiFT.

Figure S4. Promoter sequence alignment of GPT2.

Figure S5. Diffcorr networks for bipvs.Lu and HBvs.LB.

Figure S6. Gene expression patterns of Diffcorr genes.

Table S1. Differentially expressed genes for bip0663 vs. Lukullus and HB vs. LB.

Table S2. GO analysis of 57 shared DEGs.

Table S3. Literature-curated vascular related genes.

Table S4. 11 shared Diffcorr genes.

Table S5. GO terms for HB vs. LB DEGs.

Table S6. GO terms for genes highly correlated with GPT2.

Table S7. GO analysis of 5 gene co-expression network communities.

\section{DATA DEPOSITION}

RNA-seq and WGS libraries are deposited in NCBI's SRA database (Accession number

583 GitHub (https://github.com/karoczar/Sinha-Lab-Scripts).

\section{ACKNOWLEDGMENTS}

587 We acknowledge help from Mary Lee, Kirsten Brand, Gabriel Luis Moreira, Kristina Khuu, 588 Eduardo Ramirez, Divya Kumaria, and Amber M. Flores in field sample, leaf and BRIX data 589 collection, and seed collection. We also thank John Harada, Leonardo Jo, Rie Uzawa, Siyu Li, 590 and members of the Sinha Lab for advice. We also thank CyVerse for online data storage. 
Support from USDA-NIFA (grant no. 2014-67013-21700) to NRS, Rosalinde H. Russell

592 Fellowship to SDR, and JSPS KAKENHI (19K23742, 20K06682) and a JSPS Fellowship

593 (13J00161) to HN is gratefully acknowledged.

\section{FIGURE LEGENDS}

Fig.1 Leaf morphology of bip mutants and diagram of bip mutations. A, Leaves of bip mutants and their corresponding wildtype cultivars; B, Wildtype BIP gene with ELK and Homeodomain, represented by gray and black boxes, respectively. Diagram of BIP protein of bip0663 and bip2.

Fig.2 Leaf complexity, fruit BRIX, and yield of bip mutants and their corresponding isogenic cultivars. A, Leaf complexity is denoted by the number of all leaflets present on the leaf; B and C, Fruit BRIX (B) and fruit yield (C) of bip mutants and their corresponding isogenic cultivars.

Fig.3 Fruit BRIX and yield of grafts. A, Fruit BRIX; B, Yield. The grafting assay used a standard least squares model of data. Graft junctions are diagramed, bip0663 (blue) and Lukullus (red).

Fig.4 Fruit BRIX and yield of Root Grafts. A, Fruit BRIX; B, Yield. The root grafting assay used a mixed model including random effect of positional data. Graft junctions are diagramed, bip0663 (blue) and Lukullus (red).

614 Fig. 5 Quantified leaf sugar and starch contents for bip0663 and Lukullus. bip0663 has lower leaf sugar than 615 Lukullus ( $\mathrm{p}=0.0939$ ) and significantly lower leaf starch compared to Lukullus ( $\mathrm{p}=0.0074)$.

Fig.6 Leaf shape analysis. A and B, PCs of all primary leaflets measured (A) and their relationship to traditional 618 shape measures (B); C, Traditional shape measures of primary leaflets of bip2, bip0663, M82 and Lukullus.

Fig.7 Leaf photosynthesis across the whole field season. A, Photosynthetic rate and stomatal conductance were measured weekly using the LI-6400XT across the whole field growing season. PARi (B) and phiPS2 (C) was measured weekly across the whole field growing season and values are the mean measurements over time and error bars represent standard error. D, The average photosynthetic rate across whole measured season in umol $\mathrm{CO}_{2} \mathrm{~m}^{-2} \mathrm{~s}^{-1}$. 
Fig.8 Leaf vascular patterning micrographs and density analysis A, Leaf clearing images of bip mutants and their isogenic wildtype cultivars, micrographs taken at a fixed magnification of $4 \mathrm{X}$. B, Leaf vein density was measured by leaf GUI for each individual leaf disc and a mean value was calculated, error bars represent standard error. C, Correlation between leaf vein density and fruit BRIX across bip mutants and their wildtypes was analyzed using JMP with "Spearman" method.

Fig.9 Leaf Vascular Density and Fruit BRIX in Other Tested Tomato Varieties. A, Leaf clearing images of bip mutant, and other varieties, taken at a fixed magnification of $4 \times 10$. B, Leaf vascular density was measured using leaf GUI for each individual leaf disc and a mean value was calculated, and error bars represent standard error. C, BRIX of tomato fruits. D, Correlation between leaf vein density and fruit BRIX analyzed using JMP with "Pearson" method.

Fig.10 Gene Co-expression Analysis of Differentially Expressed Genes, A, Venn diagram between bip0663 vs. Lukullus differentially expressed genes, HB vs. LB (High BRIX vs. Low BRIX group) different expressed genes, and literature-curated vascular genes (LCV). B, Normalized expression of GPT2 (Solyc05g045670) in Lukullus, bip0663, M82, and bip2 in mature leaves (ML), young leaves (YL), and shoot apical meristem (SAM). C, Correlation analysis of DEGs enriched in "transcription and development" and "carbohydrate and biosynthetic"related GO terms, cut off value for Pearson correlation coefficient was "BH" adjusted $\mathrm{p}$ value $<0.05$. G6PT2 was positively correlated with many genes related to carbohydrate and biosynthetic process $(|\mathrm{r}|$ value $>0.5$ and "BH" adjusted $\mathrm{p}$ value $<0.05$ ). D, Gene co-expression network constructed across bip0663, Lukullus, bip2 and M82 using DEGs enriched in "transcription and development" and "carbohydrate and biosynthetic processes"- related GO terms. Nodes (genes) with at least one edge (298 nodes and 7517 total edges) are represented. The communities are represented by different colored nodes (C1-C5). Top DiffCorr genes (Table S5) are labeled in black, G6PT2 is circled in red.

\section{LITERATURE CITED}

Adams WW, Watson AM, Mueh KE, Amiard V, Turgeon R, Ebbert V, Logan BA, Combs AF, Demmig-Adams BJPR (2007) Photosynthetic acclimation in the context of structural constraints to carbon export from leaves. Photosynth Res 94: 455-466

\section{Allen Stevens M (1979) TOMATO QUALITY: POTENTIAL FOR DEVELOPING} CULTIVARS WITH IMPROVED FLAVOR. In Symposium on Quality of Vegetables 93, pp 317-330

Baima S, Forte V, Possenti M, Peñalosa A, Leoni G, Salvi S, Felici B, Ruberti I, Morelli G (2014) Negative feedback regulation of auxin signaling by ATHB8/ACL5-BUD2 transcription module. Molecular plant 7:1006-1025

Bakker H, Schijlen E, de Vries T, Schiphorst WECM, Jordi W, Lommen A, Bosch D, van Die I (2001) Plant members of the $\alpha 1 \rightarrow 3 / 4$-fucosyltransferase gene family encode an $\alpha 1 \rightarrow 4$ - 
fucosyltransferase, potentially involved in Lewisa biosynthesis, and two core $\alpha 1 \rightarrow 3$ fucosyltransferases1. FEBS Letters 507: 307-312

Baldwin E, Goodner K, Plotto A (2008) Interaction of volatiles, sugars, and acids on perception of tomato aroma and flavor descriptors. Journal of food science 73: S294-S307

Barkoulas M, Hay A, Kougioumoutzi E, Tsiantis M (2008) A developmental framework for dissected leaf formation in the Arabidopsis relative Cardamine hirsuta. Nature Genetics 40: 1136

Beckles D, Hong N, Stamova L, Luengwilai K (2012) Biochemical factors contributing to tomato fruit sugar content. Fruits 67:49-64

Beullens K, Mészáros P, Vermeir S, Kirsanov D, Legin A, Buysens S, Cap N, Nicolaï BM, Lammertyn J (2008) Analysis of tomato taste using two types of electronic tongues. Sensors and Actuators B: Chemical 131: 10-17

Biedroń M, Banasiak A (2018) Auxin-mediated regulation of vascular patterning in Arabidopsis thaliana leaves. Plant Cell Reports 37: 1215-1229

Bishop KA, Lemonnier P, Quebedeaux JC, Montes CM, Leakey AD, Ainsworth EA (2018) Similar photosynthetic response to elevated carbon dioxide concentration in species with different phloem loading strategies. Photosynthesis research 137: 453-464

Bonhomme V, Picq S, Gaucherel C, Claude J (2014) Momocs: Outline Analysis Using R. Journal of Statistical Software 56: 1-24

Bonke M, Thitamadee S, Mähönen AP, Hauser M-T, Helariutta Y (2003) APL regulates vascular tissue identity in Arabidopsis. Nature 426: 181-186

Boyce CK, Brodribb TJ, Feild TS, Zwieniecki MA (2009) Angiosperm leaf vein evolution was physiologically and environmentally transformative. Proceedings of the Royal Society B: Biological Sciences 276: 1771-1776

Brodribb TJ, Feild TS, Jordan GJ(2007) Leaf maximum photosynthetic rate and venation are linked by hydraulics. Plant Physiology 144(4):1890-1898

Brodribb TJ, Feild TS, Sack L (2010) Viewing leaf structure and evolution from a hydraulic perspective. Functional Plant Biology 37: 488-498

Burko Y, Ori N (2013) The tomato leaf as a model system for organogenesis. Methods Mol Biol 959:1-19

Caliman FRB, Silva DJHd, Stringheta PC, Fontes PCR, Moreira GR, Mattedi AP (2007) Relation between plant yield and fruit quality characteristics of tomato. Biosci J 24:46-52

Cataldo DA (1974) Vein Loading: The Role of the Symplast in Intercellular Transport of Carbohydrate between the Mesophyll and Minor Veins of Tobacco Leaves. Plant Physiology 53: 912-917

Chitwood DH, Kumar R, Headland LR, Ranjan A, Covington MF, Ichihashi Y, Fulop D, Jimenez-Gomez JM, Peng J, Maloof JN, Sinha NR (2013) A quantitative genetic basis for leaf morphology in a set of precisely defined tomato introgression lines. Plant Cell 25: 2465-2481

Chitwood DH, Maloof JN, Sinha NR (2013) Dynamic transcriptomic profiles between tomato and a wild relative reflect distinct developmental architectures. Plant Physiology 162: $537-552$

Cocaliadis MF, Fernandez-Munoz R, Pons C, Orzaez D, Granell A (2014) Increasing tomato fruit quality by enhancing fruit chloroplast function. A double-edged sword? J Exp Bot 65: 4589-4598 
bioRxiv preprint doi: https://doi.org/10.1101/2021.03.01.433399; this version posted March 1 2021. The copyright holder for this preprint (which was not certified by peer review) is the author/funder, who has granted bioRxiv a license to display the preprint in perpetuity. It is made available under aCC-BY 4.0 International license.

Costa-Silva J, Domingues D, Lopes FM (2017) RNA-Seq differential expression analysis: An extended review and a software tool. PloS one 12

Dyson BC, Allwood JW, Feil R, Xu Y, Miller M, Bowsher CG, Goodacre R, Lunn JE, Johnson GN (2015) Acclimation of metabolism to light in Arabidopsis thaliana: the glucose 6phosphate/phosphate translocator GPT 2 directs metabolic acclimation. Plant, cell \& environment 38: 1404-1417

Scarpella E, Marcos D, Friml J, Berleth T(2006) Control of leaf vascular patterning by polar auxin transport. Genes and development 20(8):1015-1027

Etchells JP, Turner SR (2010) The PXY-CLE41 receptor ligand pair defines a multifunctional pathway that controls the rate and orientation of vascular cell division. Development 137: 767-774

Ezer D, Shepherd SJK, Brestovitsky A, Dickinson P, Cortijo S, Charoensawan V, Box MS, Biswas S, Jaeger KE, Wigge PA (2017) The G-Box Transcriptional Regulatory Code in Arabidopsis. Plant Physiology 175: 628-640

Fukushima A (2013) DiffCorr: an R package to analyze and visualize differential correlations in biological networks. Gene 518: 209-214

Gupta S, Rosenthal DM, Stinchcombe JR and Baucom RS (2020) The remarkable morphological diversity of leaf shape in sweet potato (Ipomoea batatas): the influence of genetics, environment, and G×E. New Phytologist 225: 2183-2195

Hackel A, Schauer N, Carrari F, Fernie AR, Grimm B, Kühn C (2006) Sucrose transporter LeSUT1 and LeSUT2 inhibition affects tomato fruit development in different ways. The Plant Journal 45: 180-192

Han S, Cho H, Noh J, Qi J, Jung H-J, Nam H, Lee S, Hwang D, Greb T, Hwang I (2018) BIL1mediated MP phosphorylation integrates PXY and cytokinin signalling in secondary growth. Nature Plants 4: 605-614

Haritatos E, Medville R, Turgeon RJP (2000) Minor vein structure and sugar transport in Arabidopsis thaliana. Planta 211: 105-111

Heuvelink E, Bakker MJ, Elings A, Kaarsemaker RC, Marcelis LFM (2005) Effect of Leaf Area on Tomato Yield. Acta Horticulturae 691: 43-50

Hiratsuka K, Chua N (1997) Light Regulated Transcription in Higher Plants. J. Plant Res. 110:131-139

Ichihashi Y, Aguilar-Martinez JA, Farhi M, Chitwood DH, Kumar R, Millon LV, Peng J, Maloof JN, Sinha NR (2014) Evolutionary developmental transcriptomics reveals a gene network module regulating interspecific diversity in plant leaf shape. Proc Natl Acad Sci USA 111: E2616-2621

Jones B, Frasse P, Olmos E, Zegzouti H, Li ZG, Latché A, Pech JC, Bouzayen M (2002) Downregulation of DR12, an auxin-response-factor homolog, in the tomato results in a pleiotropic phenotype including dark green and blotchy ripening fruit. The Plant Journal 32: 603-613

Jones R, Scott S (1984) Genetic potential to improve tomato flavor in commercial F1 hybrids. Journal of the American society for horticultural science 109: 318-321

Kimura S, Koenig D, Kang J, Yoong FY, Sinha N (2008) Natural variation in leaf morphology results from mutation of a novel KNOX gene. Curr Biol 18: 672-677

Klee HJ, Tieman DM (2013) Genetic challenges of flavor improvement in tomato. Trends in Genetics 29: 257-262 
Koenig D, Bayer EM, Kang J, Kuhlemeier C, Sinha N. (2009). Auxin patterns Solanum lycopersicum leaf morphogenesis. Development 136(17): 2997-3006.

Koenig D, Jiménez-Gómez JM, Kimura S, Fulop D, Chitwood DH, Headland LR, Kumar R, Covington MF, Dvisetty UK, Tat AV, Tohge T, Bolger A, Schneeberger K, Ossowski S, Lanz C, Xiong G, Taylor-Teeples M, Brady SM, Pauly M, Weigel D, Usadel B, Fernie AR, Peng J, Sinha NR, Maloof JN (2013) Comparative transcriptomics reveals patterns of selection in domesticated and wild tomato PNAS 110: E2655-E2662

Krusell L, Rasmussen I, Gausing K (1997) DNA binding sites recognised in vitro by a knotted class 1 homeodomain protein encoded by the hooded gene, $\mathrm{k}$, in barley (Hordeum vulgare). FEBS Letters 408: 25-29

Law CW, Chen Y, Shi W, Smyth GK (2014) voom: Precision weights unlock linear model analysis tools for RNA-seq read counts. Genome biology 15: R29

Lawson T, Bryant B, Lefebvre S, Lloyd J, Raines C (2006) Decreased SBPase activity alters growth and development in transgenic tobacco plants. Plant, cell \& environment 29: 4858

Li H, Durbin R (2009) Fast and accurate short read alignment with Burrows-Wheeler Transform. Bioinformatics, 25:1754-60.

Malundo TMM, Baldwin EA, Ware GO, Shewfelt R (1996) Volatile composition and interaction influence flavor properties of mango (Mangifera indica L.). Proc. Fla. State Hort. Soc 109: 264-268

Menda, N., Semel, Y., Peled, D., Eshed, Y., Zamir, D. (2004). In silico screening of a saturated mutation library of tomato. Plant J. 38, 861-872.

Mi H, Muruganujan A, Ebert D, Huang X, Thomas PD (2019) PANTHER version 14: more genomes, a new PANTHER GO-slim and improvements in enrichment analysis tools. Nucleic Acids Research 47: D419-D426

Mitsuda N, Iwase A, Yamamoto H, Yoshida M, Seki M, Shinozaki K, Ohme-Takagi M (2007) NAC transcription factors, NST1 and NST3, are key regulators of the formation of secondary walls in woody tissues of Arabidopsis. The Plant Cell 19: 270-280

Miyashima S, Sebastian J, Lee JY, Helariutta Y (2013) Stem cell function during plant vascular development. The EMBO journal 32: 178-193

Nakayama H, Rowland SD, Zizhang C, Zumstein K, Kang J, Kondo Y, Sinha NR (2020) Leaf form diversification in an heirloom tomato results from alterations in two different HOMEOBOX genes. bioRxiv 226: 851-865

Paul AL, Zupanska AK, Schultz ER, Ferl RJ (2013) Organ-specific remodeling of the Arabidopsis transcriptome in response to spaceflight. BMC Plant Biol 13:112

Parsons-Wingerter P, Vickerman MB, Paul AL, Ferl RJ (2014) Mapping by VESGEN of Leaf Venation Patterning in Arabidopsis thaliana with Bioinformatic Dimension of Gene Expression. Gravitational and Space Research 2: 68-81.

Price CA (2012) LEAF GUI: analyzing the geometry of veins and areoles using image segmentation algorithms. In High-throughput phenotyping in plants. Springer, pp 41-49

Raines C, Paul M (2006) Products of leaf primary carbon metabolism modulate the developmental programme determining plant morphology. Journal of experimental botany 57: 1857-1862

Rowland SD, Zumstein K, Nakayama H, Cheng Z, Flores AM, Chitwood DH, Maloof JN, Sinha NR (2019) Leaf shape is a predictor of fruit quality and cultivar performance in tomato. New Phytologist 
Russin WA, Evert RF (1984) Studies on the leaf of Populus deltoides (Salicaceae): morphology and anatomy. American Journal of Botany 71: 1398-1415

Sack L, Frole K (2006) Leaf structural diversity is related to hydraulic capacity in tropical rain forest trees. Ecology 87: 483-491

Sack L, Scoffoni C (2013) Leaf venation: structure, function, development, evolution, ecology and applications in the past, present and future. New Phytol 198: 983-1000

Sagar M, Chervin C, Mila I, Hao Y, Roustan J-P, Benichou M, Gibon Y, Biais B, Maury P, Latché A (2013) SlARF4, an auxin response factor involved in the control of sugar metabolism during tomato fruit development. Plant physiology 161: 1362-1374

Sarlikioti V, de Visser PH, Buck-Sorlin G, Marcelis L (2011) How plant architecture affects light absorption and photosynthesis in tomato: towards an ideotype for plant architecture using a functional-structural plant model. Annals of Botany 108: 1065-1073

Shahmuradov I, Solovyev V (2015) Nsite, NsiteH and NsiteM Computer Tools for Studying Transcription Regulatory Elements. Bioinformatics 31: 3544-3545

Shannon P, Markiel A, Ozier O, Baliga NS, Wang JT, Ramage D, Amin A, Schwikowski B, Ideker T (2003) Cytoscape: A Software Environment for Integrated Models of Biomolecular Interaction Networks. Genome Res 13: 2498-2504

Smith WK, Vogelmann TC, DeLucia EH, Bell DT, Shepherd KA (1997) Leaf Form and Photosynthesis. BioScience 47: 785-793

Thomas PD, Campbell MJ, Kejariwal A, Mi H, Karlak B, Daverman R, Diemer K, Muruganujan A, Narechania A. 2003. PANTHER: a library of protein families and subfamilies indexed by function. Genome Res 13: 2129-2141

Tieman D, Bliss P, McIntyre LM, Blandon-Ubeda A, Bies D, Odabasi AZ, Rodríguez GR, van der Knaap E, Taylor MG, Goulet C (2012) The chemical interactions underlying tomato flavor preferences. Current Biology 22: 1035-1039

Tieman D, Zhu G, Resende MFR, Lin T, Nguyen C, Bies D, Rambla JL, Beltran KSO, Taylor M, Zhang B, Ikeda H, Liu Z, Fisher J, Zemach I, Monforte A, Zamir D, Granell A, Kirst M, Huang S, Klee H (2017) A chemical genetic roadmap to improved tomato flavor. Science 355: 391

Townsley BT, Covington MF, Ichihashi Y, Zumstein K, Sinha NR (2015) BrAD-seq: Breath Adapter Directional sequencing: a streamlined, ultra-simple and fast library preparation protocol for strand specific mRNA library construction. Front Plant Sci 6: 366

Townsley BT, Sinha NR (2012) A new development: evolving concepts in leaf ontogeny. Annual review of plant biology 63

Van Dingenen J, De Milde L, Vermeersch M, Maleux K, De Rycke R, De Bruyne M, Storme V, Gonzalez N, Dhondt S, Inzé D (2016) Chloroplasts Are Central Players in Sugar-Induced Leaf Growth. Plant Physiology 171: 590-605

Wang D, Seymour G (2017) Tomato Flavor: Lost and Found? Molecular Plant 10:782-784

Wenzel CL, Hester Q, Mattsson J (2008) Identification of genes expressed in vascular tissues using NPA-induced vascular overgrowth in Arabidopsis. Plant Cell Physiol 49: 457-468

Xiao H, Jiang N, Schaffner E, Stockinger EJ, van der Knaap E (2008) A RetrotransposonMediated Gene Duplication Underlies Morphological Variation of Tomato Fruit. Science 319: 1527

Yamaguchi M, Goué N, Igarashi H, Ohtani M, Nakano Y, Mortimer JC, Nishikubo N, Kubo M, Katayama Y, Kakegawa K, Dupree P, Demura T (2010) VASCULAR-RELATED NACDOMAIN6 and VASCULAR-RELATED NAC-DOMAIN7 Effectively Induce 
Transdifferentiation into Xylem Vessel Elements under Control of an Induction System.

$845 \quad$ Plant Physiology 153: 906-914

Yifhar T, Pekker I, Peled D, Friedlander G, Pistunov A, Sabban M, Wachsman G, Alvarez JP, Amsellem Z, Eshed Y (2012) Failure of the tomato trans-acting short interfering RNA program to regulate AUXIN RESPONSE FACTOR3 and ARF4 underlies the wiry leaf syndrome. The Plant Cell 24: 3575-3589 RNA-seq datasets. R Bioconductor 8: 1-25 


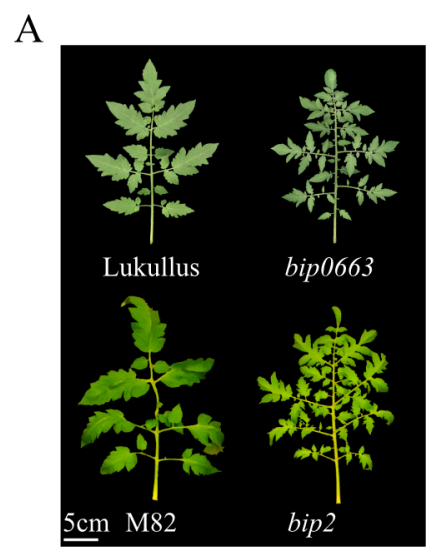

B
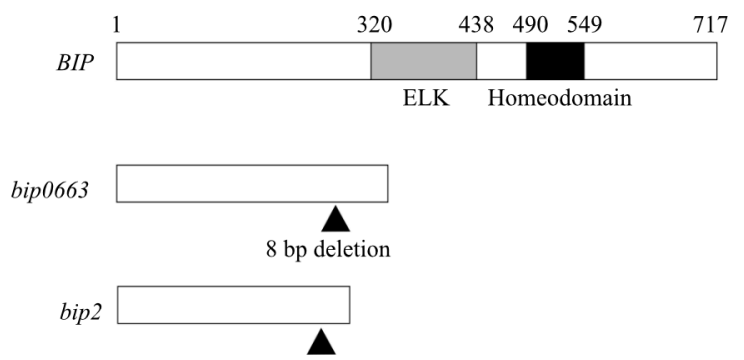

29 bp replacement with a single nucleotide

Fig.1 Leaf morphology of bip mutants and diagram of bip mutations. A, Leaves of bip mutants and their corresponding wildtype cultivars; B, Wildtype BIP gene with ELK and Homeodomain, represented by gray and black boxes, respectively. Diagram of BIP protein of bip0663 and bip2. 
A

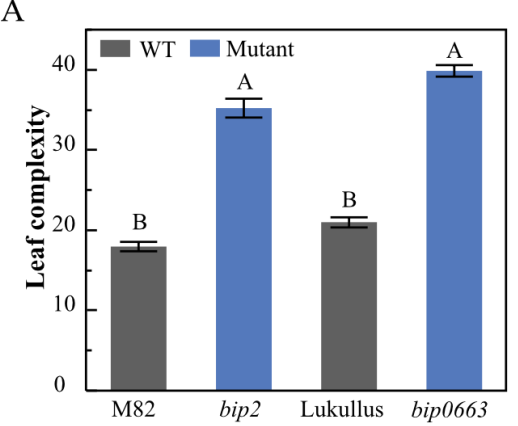

B

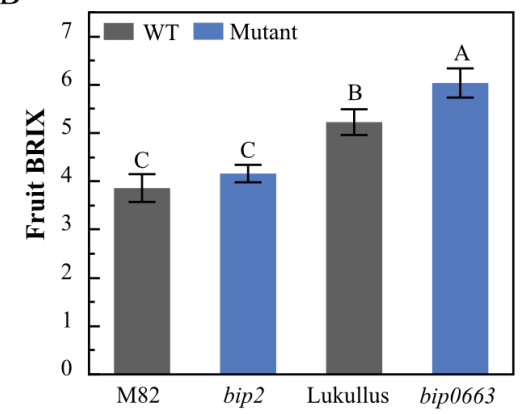

$\mathrm{C}$

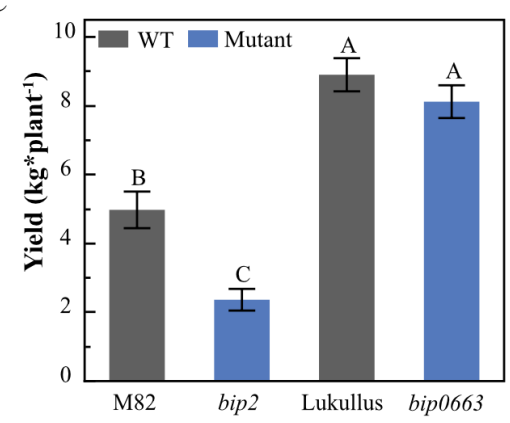

Fig.2 Leaf complexity, fruit BRIX, and yield of bip mutants and their corresponding isogenic cultivars.

A, Leaf complexity is denoted by the number of all leaflets present on the leaf; B and C, Fruit BRIX (B) and fruit yield (C) of bip mutants and their corresponding isogenic cultivars. 

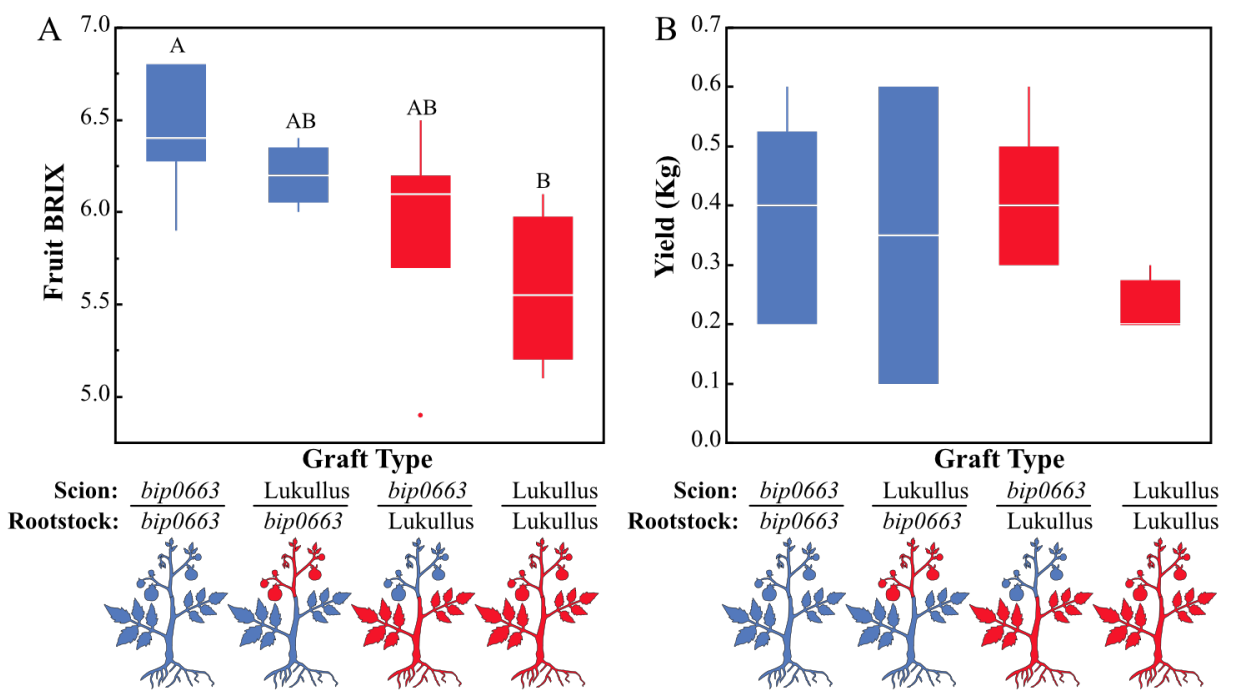

Fig.3 Fruit BRIX and yield of grafts. A, Fruit BRIX; B, Yield. The grafting assay used a standard least squares model of data. Graft junctions are diagramed, bip0663 (blue) and Lukullus (red). 


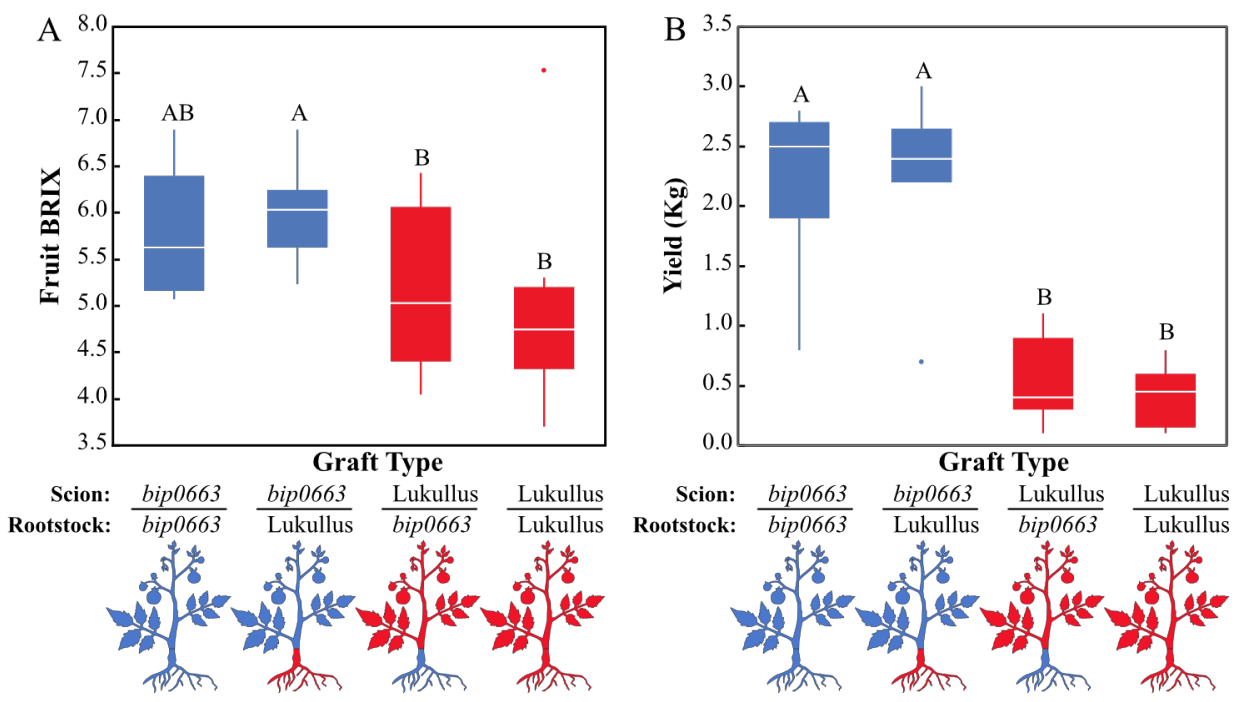

Fig.4 Fruit BRIX and yield of Root Grafts. A, Fruit BRIX; B, Yield. The root grafting assay used a mixed model including random effect of positional data. Graft junctions are diagramed, bip0663 (blue) and Lukullus (red). 
bioRxiv preprint doi: https://doi.org/10.1101/2021.03.01.433399; this version posted March 1, 2021. The copyright holder for this preprint (which was not certified by peer review) is the author/funder, who has granted bioRxiv a license to display the preprint in perpetuity. It is made available under aCC-BY 4.0 International license.

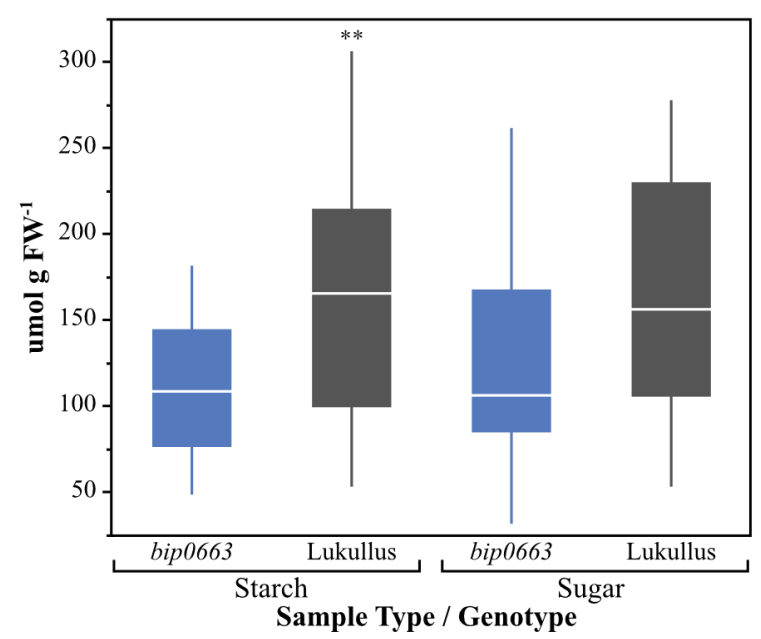

Fig. 5 Quantified leaf sugar and starch contents for bip0663 and Lukullus. bip0663 has lower leaf sugar than Lukullus $(p=0.0939)$ and significantly lower leaf starch compared to Lukullus $(p=0.0074)$. 
A

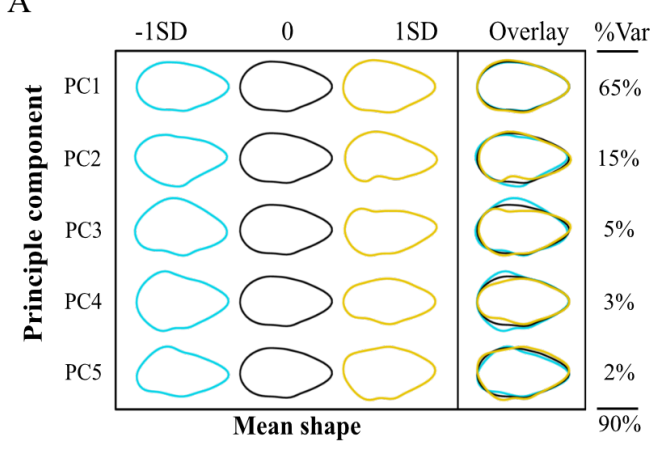

$\mathrm{C}$

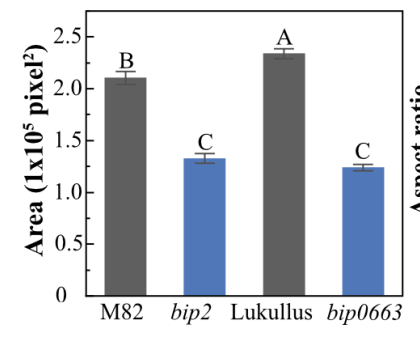

$\mathrm{B}$
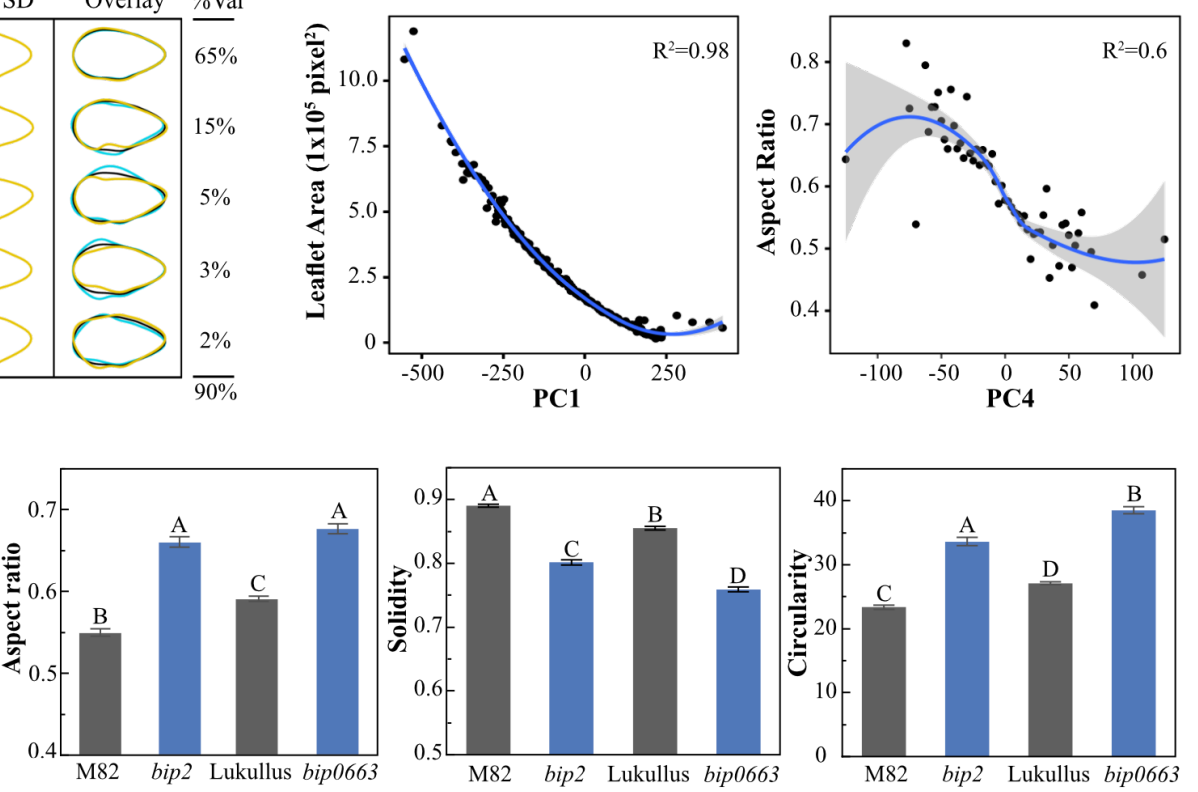

Fig.6 Leaf shape analysis. A and B, PCs of all primary leaflets measured (A) and their relationship to traditional shape measures (B); C, Traditional shape measures of primary leaflets of bip2, bip0663, M82 and Lukullus. 
A

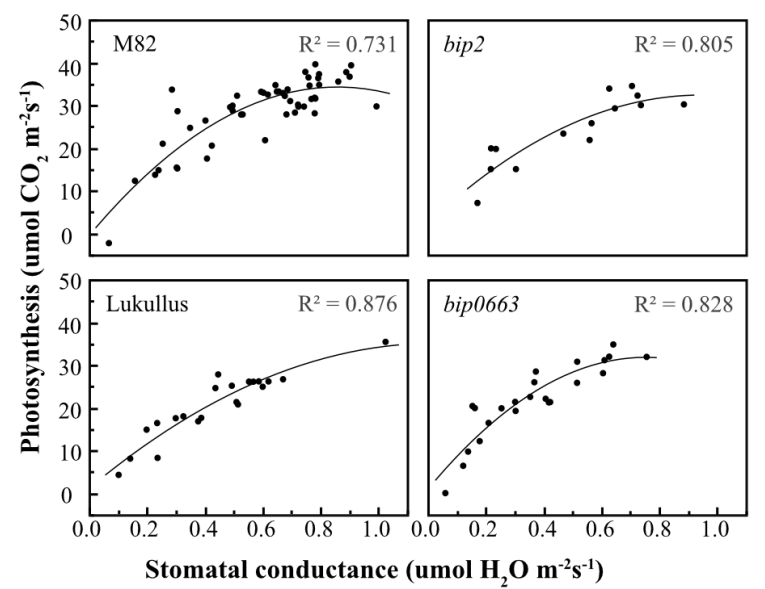

$\mathrm{C}$

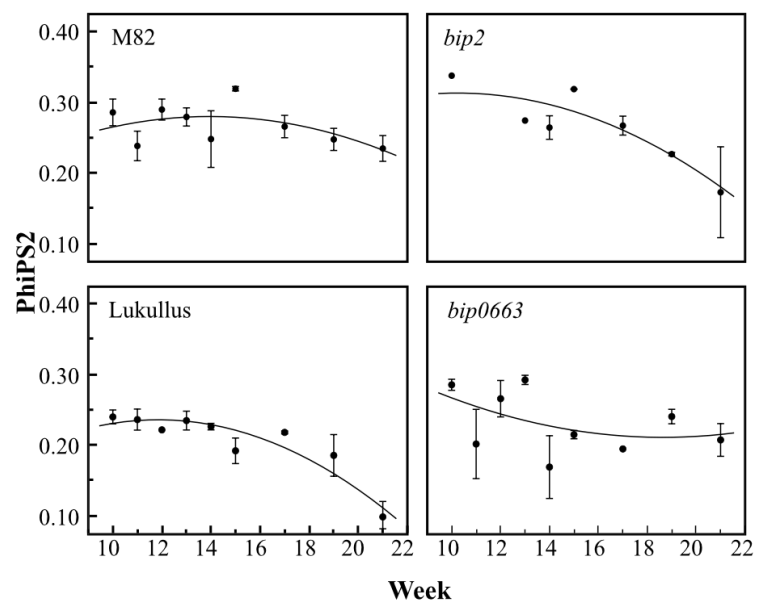

$\mathrm{B}$

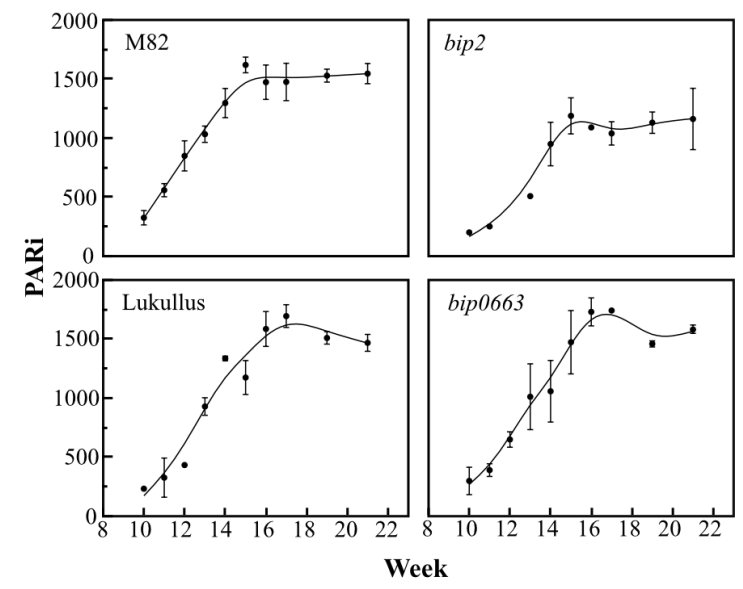

$\mathrm{D}$

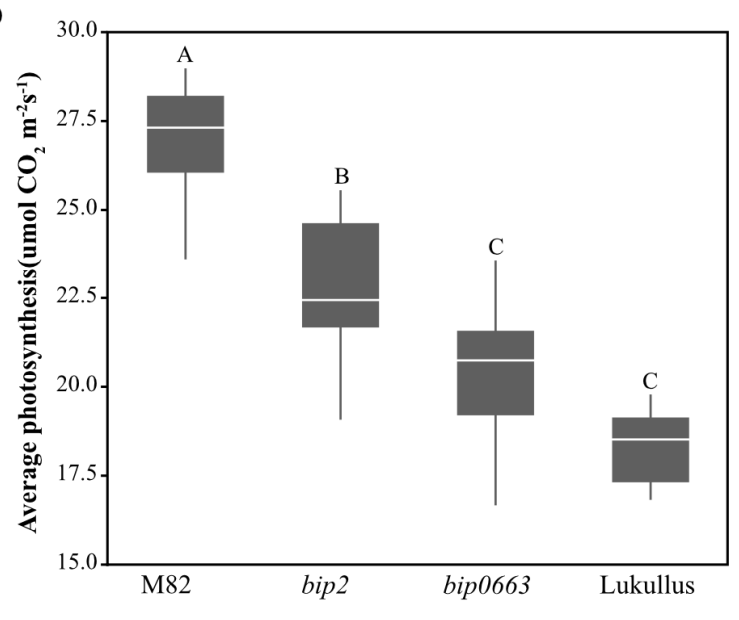

Fig.7 Leaf photosynthesis across the whole field season. A, Photosynthetic rate and stomatal conductance were measured weekly using the LI-6400XT across the whole field growing season. PARi (B) and phiPS2 (C) was measured weekly across the whole field growing season and values are the mean measurements over time and error bars represent standard error. D, The average photosynthetic rate across whole measured season in umol CO $\mathrm{Cm}^{-2} \mathrm{~s}^{-1}$. 
A

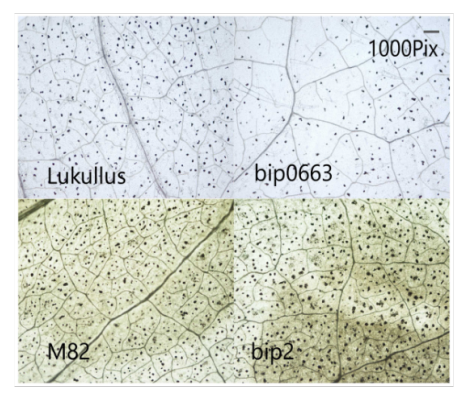

B

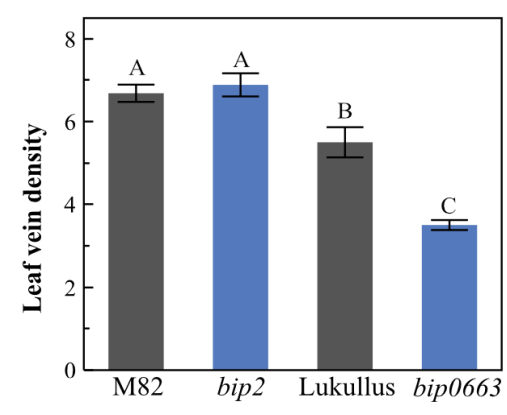

$\mathrm{C}$

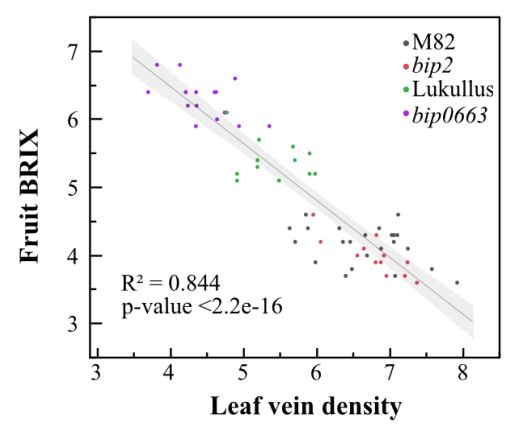

Fig.8 Leaf vascular patterning micrographs and density analysis A, Leaf clearing images of bip mutants and their isogenic wildtype cultivars, micrographs taken at a fixed magnification of $4 \mathrm{X}$. B, Leaf vein density was measured by leaf GUI for each individual leaf disc and a mean value was calculated, error bars represent standard error. C, Correlation between leaf vein density and fruit BRIX across bip mutants and their wildtypes was analyzed using JMP with "Spearman" method. 


\section{A}

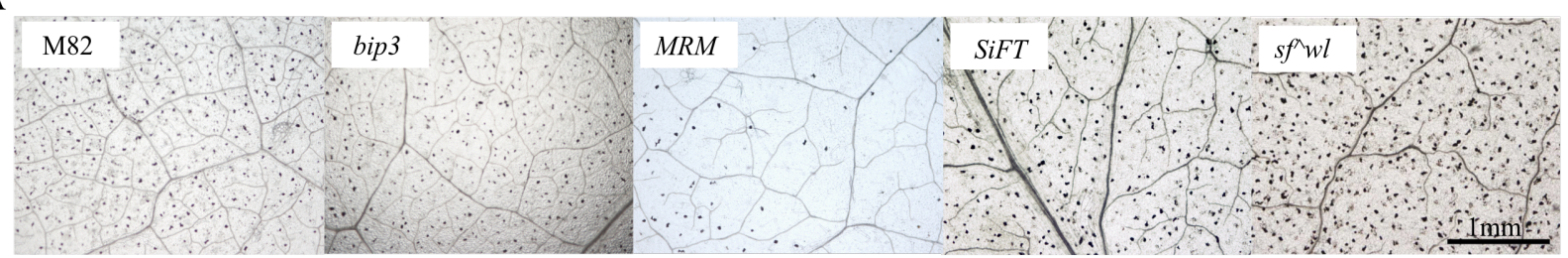

B

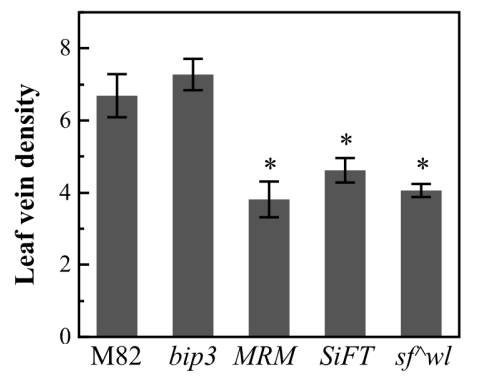

C

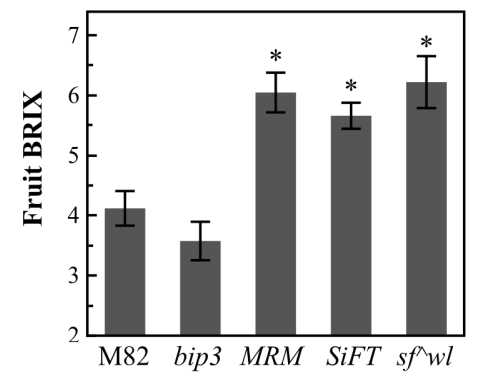

$\mathrm{D}$

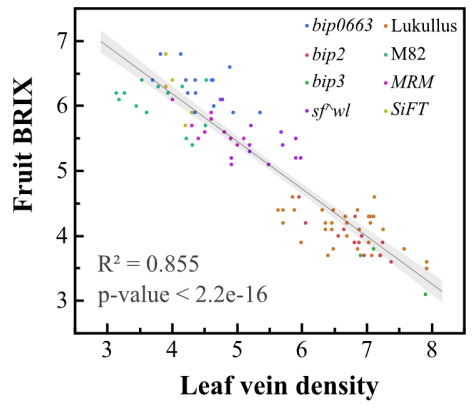

Fig.9 Leaf Vascular Density and Fruit BRIX in Other Tested Tomato Varieties. A, Leaf clearing images of bip mutant, and other varieties, taken at a fixed magnification of $4 \times 10$. B, Leaf vascular density was measured using leaf GUI for each individual leaf disc and a mean value was calculated, and error bars represent standard error. C, BRIX of tomato fruits. D, Correlation between leaf vein density and fruit BRIX analyzed using JMP with "Pearson" method. 
bioRxiv preprint doi: https://doi.org/10.1101/2021.03.01.433399; this version posted March 1, 2021. The copyright holder for this preprint (which was not certified by peer review) is the author/funder, who has granted bioRxiv a license to display the preprint in perpetuity. It is made available under aCC-BY 4.0 International license.

A

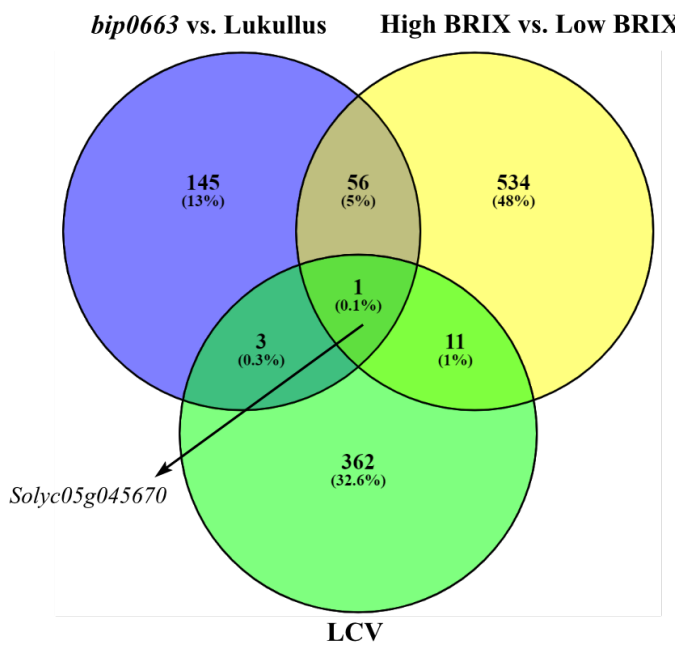

$\mathrm{C}$

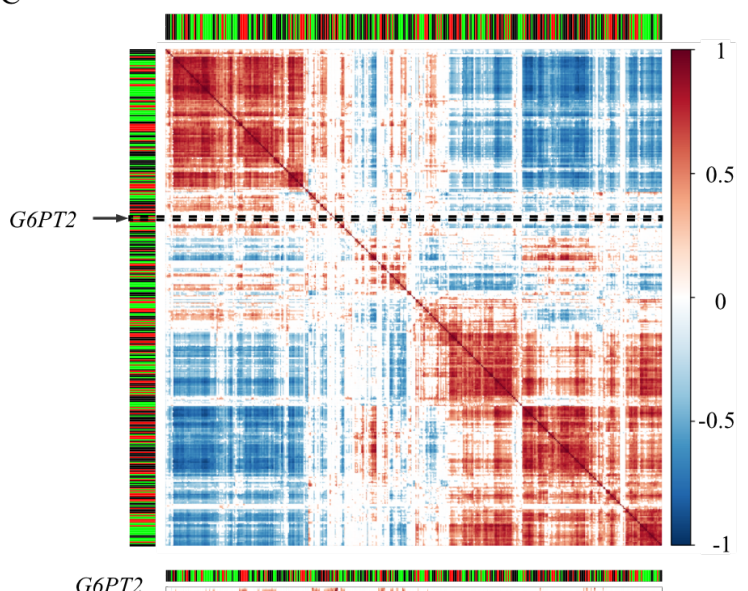

G6PT2

$1 . \mathrm{r}$ value, cutoff values for $\mathrm{r}$ " $\mathrm{BH}$ " adjusted $\mathrm{p}<0.05$

"carbohydrate and biosynthetic" related gene

- "transcription and development" related gene

"transcription, development" and "carbohydrate and biosynthetic" related
B

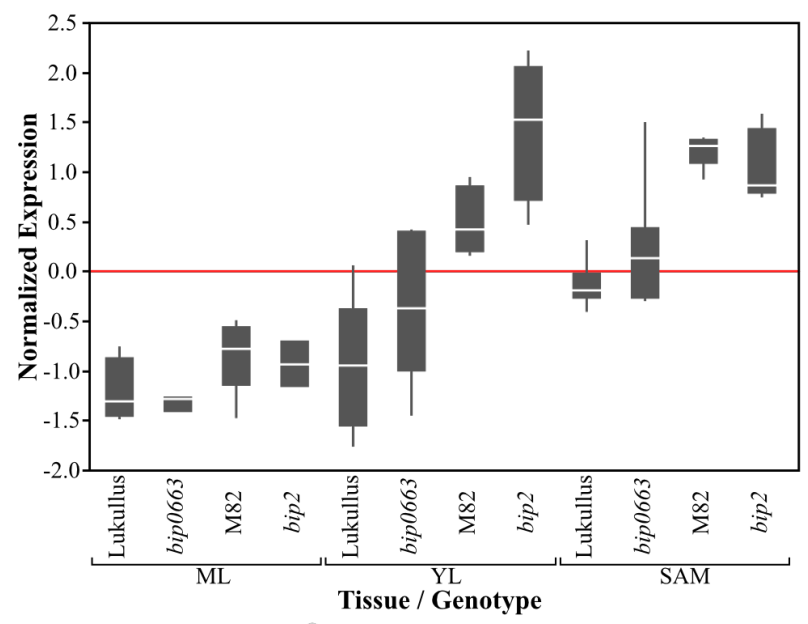

$\mathrm{D}$

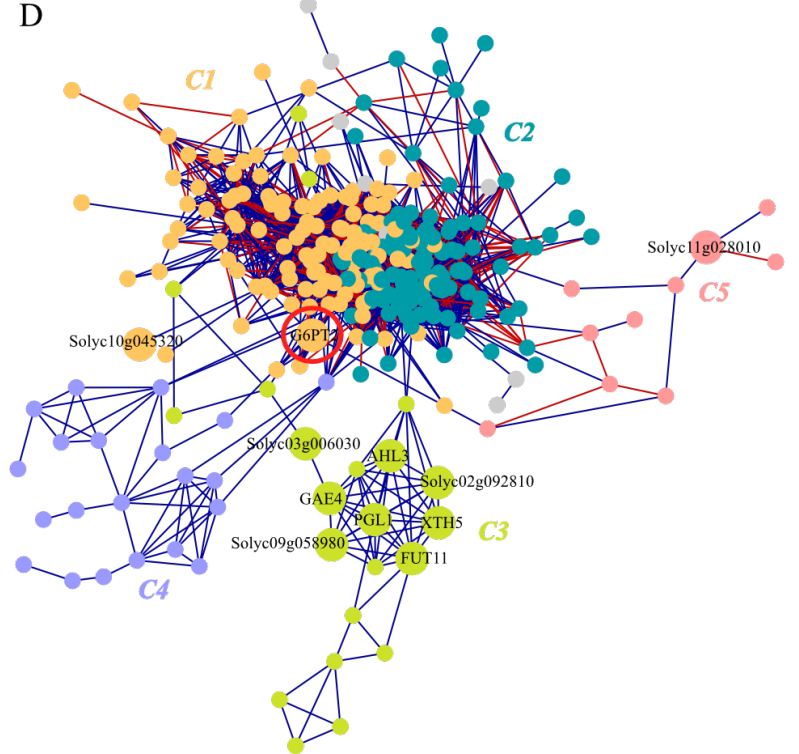

Fig.10 Gene Co-expression Analysis of Differentially Expressed Genes, A, Venn diagram between bip0663 vs.

Lukullus differentially expressed genes, HB vs. LB (High BRIX vs. Low BRIX group) different expressed genes, and literature-curated vascular genes (LCV). B, Normalized expression of GPT2 (Solyc05g045670) in Lukullus, bip0663, M82, and bip2 in mature leaves (ML), young leaves (YL), and shoot apical meristem (SAM). C, Correlation analysis of DEGs enriched in "transcription and development" and "carbohydrate and biosynthetic"related GO terms, cut off value for Pearson correlation coefficient was "BH" adjusted $\mathrm{p}$ value $<0.05$. G6PT2 was positively correlated with many genes related to carbohydrate and biosynthetic process $(|\mathrm{r}|$ value $>0.5$ and "BH" adjusted $\mathrm{p}$ value $<0.05$ ). D, Gene co-expression network constructed across bip0663, Lukullus, bip2 and M82 using DEGs enriched in "transcription and development" and "carbohydrate and biosynthetic processes"- related GO terms. Nodes (genes) with at least one edge (298 nodes and 7517 total edges) are represented. The communities are represented by different colored nodes (C1-C5). Top DiffCorr genes (Table S5) are labeled in black, G6PT2 is circled in red. 


\section{Parsed Citations}

Adams WW, Watson AM, Mueh KE, Amiard V, Turgeon R, Ebbert V, Logan BA, Combs AF, Demmig-Adams BJPR (2007) Photosynthetic acclimation in the context of structural constraints to carbon export from leaves. Photosynth Res 94: 455-466

Google Scholar: Author Only Title Only Author and Title

Allen Stevens M (1979) TOMATO QUALITY: POTENTIAL FOR DEVELOPING CULTIVARS WTH IMPROVED FLAVOR. In Symposium on Quality of Vegetables 93, pp 317-330

Google Scholar: Author Only Title Only Author and Title

Baima S, Forte V, Possenti M, Peñalosa A, Leoni G, Salvi S, Felici B, Ruberti I, Morelli G (2014) Negative feedback regulation of auxin signaling by ATHB8/ACL5-BUD2 transcription module. Molecular plant 7:1006-1025

Google Scholar: Author Only Title Only Author and Title

Bakker H, Schijlen E, de Vries T, Schiphorst WECM, Jordi W, Lommen A, Bosch D, van Die I (2001) Plant members of the $\alpha 1 \rightarrow 3 / 4-$ fucosyltransferase gene family encode an $\alpha 1 \rightarrow 4$-fucosyltransferase, potentially involved in Lewisa biosynthesis, and two core $\alpha 1 \rightarrow 3$ fucosyltransferases1. FEBS Letters 507: 307-312

Google Scholar: Author Only Title Only Author and Title

Baldwin E, Goodner K, Plotto A(2008) Interaction of volatiles, sugars, and acids on perception of tomato aroma and flavor descriptors. Journal of food science 73: S294-S307

Google Scholar: Author Only Title Only Author and Title

Barkoulas M, Hay A, Kougioumoutzi E, Tsiantis M (2008) Adevelopmental framework for dissected leaf formation in the Arabidopsis relative Cardamine hirsuta. Nature Genetics 40: 1136

Google Scholar: Author Only Title Only Author and Title

Beckles D, Hong N, Stamova L, Luengwilai K (2012) Biochemical factors contributing to tomato fruit sugar content. Fruits 67:49-64

Google Scholar: Author Only Title Only Author and Title

Beullens K, Mészáros P, Vermeir S, Kirsanov D, Legin A, Buysens S, Cap N, Nicolaï BM, Lammertyn J (2008) Analysis of tomato taste using two types of electronic tongues. Sensors and Actuators B: Chemical 131: 10-17

Google Scholar: Author Only Title Only Author and Title

Biedroń M, Banasiak A(2018) Auxin-mediated regulation of vascular patterning in Arabidopsis thaliana leaves. Plant Cell Reports 37: 1215-1229

Google Scholar: Author Only Title Only Author and Title

Bishop KA, Lemonnier P, Quebedeaux JC, Montes CM, Leakey AD, Ainsworth EA(2018) Similar photosynthetic response to elevated carbon dioxide concentration in species with different phloem loading strategies. Photosynthesis research 137: 453-464

Google Scholar: Author Only Title Only Author and Title

Bonhomme V, Picq S, Gaucherel C, Claude J (2014) Momocs: Outline Analysis Using R. Journal of Statistical Software 56: 1-24

Google Scholar: Author Only Title Only Author and Title

Bonke M, Thitamadee S, Mähönen AP, Hauser M-T, Helariutta Y (2003) APL regulates vascular tissue identity in Arabidopsis. Nature 426: 181-186

Google Scholar: Author Only Title Only Author and Title

Boyce CK, Brodribb TJ, Feild TS, Zwieniecki MA(2009) Angiosperm leaf vein evolution was physiologically and environmentally transformative. Proceedings of the Royal Society B: Biological Sciences 276: 1771-1776

Google Scholar: Author Only Title Only Author and Title

Brodribb TJ, Feild TS, Jordan GJ(2007) Leaf maximum photosynthetic rate and venation are linked by hydraulics. Plant Physiology 144(4):1890-1898

Google Scholar: Author Only Title Only Author and Title

Brodribb TJ, Feild TS, Sack L (2010) Viewing leaf structure and evolution from a hydraulic perspective. Functional Plant Biology 37 : 488-498

Google Scholar: Author Only Title Only Author and Title

Burko Y, Ori N (2013) The tomato leaf as a model system for organogenesis. Methods Mol Biol 959:1-19

Google Scholar: Author Only Title Only Author and Title

Caliman FRB, Silva DJHd, Stringheta PC, Fontes PCR, Moreira GR, Mattedi AP (2007) Relation between plant yield and fruit quality characteristics of tomato. Biosci J 24:46-52

Google Scholar: Author Only Title Only Author and Title

Cataldo DA(1974) Vein Loading: The Role of the Symplast in Intercellular Transport of Carbohydrate between the Mesophyll and Minor Veins of Tobacco Leaves. Plant Physiology 53: 912-917

Google Scholar: Author Only Title Only Author and Title

Chitwood DH, Kumar R, Headland LR, Ranjan A, Covington MF, Ichihashi Y, Fulop D, Jimenez-Gomez JM, Peng J, Maloof JN, Sinha NR 

available under aCC-BY 4.0 International license.

(2013) A quantitative genetic basis for leaf morphology in a set of precisely defined tomato introgression lines. Plant Cell 25: 2465-2481 Google Scholar: Author Only Title Only Author and Title

Chitwood DH, Maloof JN, Sinha NR (2013) Dynamic transcriptomic profiles between tomato and a wild relative reflect distinct developmental architectures. Plant Physiology 162: 537-552

Google Scholar: Author Only Title Only Author and Title

Cocaliadis MF, Fernandez-Munoz R, Pons C, Orzaez D, Granell A(2014) Increasing tomato fruit quality by enhancing fruit chloroplast function. Adouble-edged sword? J Exp Bot 65: 4589-4598

Google Scholar: Author Only Title Only Author and Title

Costa-Silva J, Domingues D, Lopes FM (2017) RNASeq differential expression analysis: An extended review and a software tool. PloS one 12

Google Scholar: Author Only Title Only Author and Title

Dyson BC, Alwood JW, Feil R, Xu Y, Miller M, Bowsher CG, Goodacre R, Lunn JE, Johnson GN (2015) Acclimation of metabolism to light in Arabidopsis thaliana: the glucose 6-phosphate/phosphate translocator GPT 2 directs metabolic acclimation. Plant, cell \& environment 38: 1404-1417

Google Scholar: Author Only Title Only Author and Title

Scarpella E, Marcos D, Friml J, Berleth T(2006) Control of leaf vascular patterning by polar auxin transport. Genes and development 20(8):1015-1027

Google Scholar: Author Only Title Only Author and Title

Etchells JP, Turner SR (2010) The PXY-CLE41 receptor ligand pair defines a multifunctional pathway that controls the rate and orientation of vascular cell division. Development 137: 767-774

Google Scholar: Author Only Title Only Author and Title

Ezer D, Shepherd SJK, Brestovitsky A Dickinson P, Cortijo S, Charoensawan V, Box MS, Biswas S, Jaeger KE, Wigge PA(2017) The GBox Transcriptional Regulatory Code in Arabidopsis. Plant Physiology 175: 628-640

Google Scholar: Author Only Title Only Author and Title

Fukushima A(2013) DiffCorr: an R package to analyze and visualize differential correlations in biological networks. Gene 518: 209-214 Google Scholar: Author Only Title Only Author and Title

Gupta S, Rosenthal DM, Stinchcombe JR and Baucom RS (2020) The remarkable morphological diversity of leaf shape in sweet potato (Ipomoea batatas): the influence of genetics, environment, and GxE. New Phytologist 225: 2183-2195

Google Scholar: Author Only Title Only Author and Title

Hackel A, Schauer N, Carrari F, Fernie AR, Grimm B, Kühn C (2006) Sucrose transporter LeSUT1 and LeSUT2 inhibition affects tomato fruit development in different ways. The Plant Journal 45: 180-192

Google Scholar: Author Only Title Only Author and Title

Han S, Cho H, Noh J, Qi J, Jung H-J, Nam H, Lee S, Hwang D, Greb T, Hwang I (2018) BIL1-mediated MP phosphorylation integrates PXY and cytokinin signalling in secondary growth. Nature Plants 4: 605-614

Google Scholar: Author Only Title Only Author and Title

Haritatos E, Medville R, Turgeon RJP (2000) Minor vein structure and sugar transport in Arabidopsis thaliana. Planta 211: 105-111 Google Scholar: Author Only Title Only Author and Title

Heuvelink E, Bakker MJ, Elings A, Kaarsemaker RC, Marcelis LFM (2005) Effect of Leaf Area on Tomato Yield. Acta Horticulturae 691: 43-50

Google Scholar: Author Only Title Only $\underline{\text { Author and Title }}$

Hiratsuka K, Chua N (1997) Light Regulated Transcription in Higher Plants. J. Plant Res. 110:131-139

Google Scholar: Author Only Title Only Author and Title

Ichihashi Y, Aguilar-Martinez JA, Farhi M, Chitwood DH, Kumar R, Millon LV, Peng J, Maloof JN, Sinha NR (2014) Evolutionary developmental transcriptomics reveals a gene network module regulating interspecific diversity in plant leaf shape. Proc Natl Acad Sci USA 111: E2616-2621

Google Scholar: Author Only Title Only Author and Title

Jones B, Frasse P, Olmos E, Zegzouti H, Li ZG, Latché A, Pech JC, Bouzayen M (2002) Down-regulation of DR12, an auxin-responsefactor homolog, in the tomato results in a pleiotropic phenotype including dark green and blotchy ripening fruit. The Plant Journal 32: 603-613

Google Scholar: Author Only Title Only Author and Title

Jones R, Scott S (1984) Genetic potential to improve tomato flavor in commercial F1 hybrids. Journal of the American society for horticultural science 109: 318-321

Google Scholar: Author Only Title Only Author and Title

Kimura S, Koenig D, Kang J, Yoong FY, Sinha N (2008) Natural variation in leaf morphology results from mutation of a novel KNOX gene. Curr Biol 18: 672-677

Google Scholar: Author Only Title Only Author and Title 

available under aCC-BY 4.0 International license.

Klee HJ, Tieman DM (2013) Genetic challenges of flavor improvement in tomato. Trends in Genetics 29: 257-262

Google Scholar: Author Only Title Only Author and Title

Koenig D, Bayer EM, Kang J, Kuhlemeier C, Sinha N. (2009). Auxin patterns Solanum lycopersicum leaf morphogenesis. Development 136(17): 2997-3006.

Google Scholar: Author Only Title Only Author and Title

Koenig D, Jiménez-Gómez JM, Kimura S, Fulop D, Chitwood DH, Headland LR, Kumar R, Covington MF, Dvisetty UK, Tat AV, Tohge T, Bolger A, Schneeberger K, Ossowski S, Lanz C, Xiong G, Taylor-Teeples M, Brady SM, Pauly M, Weigel D, Usadel B, Fernie AR, Peng J, Sinha NR, Maloof JN (2013) Comparative transcriptomics reveals patterns of selection in domesticated and wild tomato PNAS 110: E2655-E2662

Google Scholar: Author Only Title Only Author and Title

Krusell L, Rasmussen I, Gausing K (1997) DNA binding sites recognised in vitro by a knotted class 1 homeodomain protein encoded by the hooded gene, $k$, in barley (Hordeum vulgare). FEBS Letters 408: 25-29

Google Scholar: Author Only Title Only Author and Title

Law CW, Chen Y, Shi W, Smyth GK (2014) voom: Precision weights unlock linear model analysis tools for RNAseq read counts. Genome biology 15: R29

Google Scholar: Author Only Title Only Author and Title

Lawson T, Bryant B, Lefebvre S, Lloyd J, Raines C (2006) Decreased SBPase activity alters growth and development in transgenic tobacco plants. Plant, cell \& environment 29: 48-58

Google Scholar: Author Only Title Only Author and Title

Li H, Durbin R (2009) Fast and accurate short read alignment with Burrows-Wheeler Transform Bioinformatics, 25:1754-60.

Google Scholar: Author Only Title Only Author and Title

Malundo TMM, Baldwin EA, Ware GO, Shewfelt R (1996) Volatile composition and interaction influence flavor properties of mango (Mangifera indica L.). Proc. Fla. State Hort. Soc 109: 264-268

Google Scholar: Author Only Title Only Author and Title

Menda, N., Semel, Y., Peled, D., Eshed, Y., Zamir, D. (2004). In silico screening of a saturated mutation library of tomato. Plant J. 38, 861872.

Google Scholar: Author Only Title Only Author and Title

Mi H, Muruganujan A, Ebert D, Huang X, Thomas PD (2019) PANTHER version 14: more genomes, a new PANTHER GO-slim and improvements in enrichment analysis tools. Nucleic Acids Research 47: D419-D426

Google Scholar: Author Only Title Only Author and Title

Mitsuda N, Iwase A, Yamamoto H, Yoshida M, Seki M, Shinozaki K, Ohme-Takagi M (2007) NAC transcription factors, NST1 and NST3, are key regulators of the formation of secondary walls in woody tissues of Arabidopsis. The Plant Cell 19: 270-280

Google Scholar: Author Only Title Only Author and Title

Miyashima S, Sebastian J, Lee JY, Helariutta Y (2013) Stem cell function during plant vascular development. The EMBO journal 32: 178193

Google Scholar: Author Only Title Only Author and Title

Nakayama H, Rowland SD, Zzhang C, Zumstein K, Kang J, Kondo Y, Sinha NR (2020) Leaf form diversification in an heirloom tomato results from alterations in two different HOMEOBOX genes. bioRxiv 226: 851-865

Google Scholar: Author Only Title Only Author and Title

Paul AL, Zupanska AK, Schultz ER, Ferl RJ (2013) Organ-specific remodeling of the Arabidopsis transcriptome in response to spaceflight. BMC Plant Biol 13:112

Google Scholar: Author Only Title Only Author and Title

Parsons-Wingerter P, Vickerman MB, Paul AL, Ferl RJ (2014) Mapping by VESGEN of Leaf Venation Patterning in Arabidopsis thaliana with Bioinformatic Dimension of Gene Expression. Gravitational and Space Research 2: 68-81.

Google Scholar: Author Only Title Only Author and Title

Price CA(2012) LEAF GUI: analyzing the geometry of veins and areoles using image segmentation algorithms. In High-throughput phenotyping in plants. Springer, pp 41-49

Google Scholar: Author Only Title Only Author and Title

Raines C, Paul M (2006) Products of leaf primary carbon metabolism modulate the developmental programme determining plant morphology. Journal of experimental botany 57: 1857-1862

Google Scholar: Author Only Title Only Author and Title

Rowland SD, Zumstein K, Nakayama H, Cheng Z, Flores AM, Chitwood DH, Maloof JN, Sinha NR (2019) Leaf shape is a predictor of fruit quality and cultivar performance in tomato. New Phytologist

Google Scholar: Author Only Title Only Author and Title

Russin WA, Evert RF (1984) Studies on the leaf of Populus deltoides (Salicaceae): morphology and anatomy. American Journal of 
Google Scholar: Author Only Title Only Author and Title

Sack L, Frole K (2006) Leaf structural diversity is related to hydraulic capacity in tropical rain forest trees. Ecology 87: 483-491 Google Scholar: Author Only Title Only Author and Title

Sack L, Scoffoni C (2013) Leaf venation: structure, function, development, evolution, ecology and applications in the past, present and future. New Phytol 198: 983-1000

Google Scholar: Author Only Title Only Author and Title

Sagar M, Chervin C, Mila I, Hao Y, Roustan J-P, Benichou M, Gibon Y, Biais B, Maury P, Latché A(2013) SIARF4, an auxin response factor involved in the control of sugar metabolism during tomato fruit development. Plant physiology 161: 1362-1374

Google Scholar: Author Only Title Only Author and Title

Sarlikioti V, de Visser PH, Buck-Sorlin G, Marcelis L (2011) How plant architecture affects light absorption and photosynthesis in tomato: towards an ideotype for plant architecture using a functional-structural plant model. Annals of Botany 108: 1065-1073

Google Scholar: Author Only Title Only Author and Title

Shahmuradov I, Solovyev V (2015) Nsite, NsiteH and NsiteM Computer Tools for Studying Transcription Regulatory Elements. Bioinformatics 31: 3544-3545

Google Scholar: Author Only Title Only Author and Title

Shannon P, Markiel A, Ozier O, Baliga NS, Wang JT, Ramage D, Amin A, Schwikowski B, Ideker T (2003) Cytoscape: A Software Environment for Integrated Models of Biomolecular Interaction Networks. Genome Res 13: 2498-2504

Google Scholar: Author Only Title Only Author and Title

Smith WK, Vogelmann TC, DeLucia EH, Bell DT, Shepherd KA(1997) Leaf Form and Photosynthesis. BioScience 47: 785-793

Google Scholar: Author Only Title Only Author and Title

Thomas PD, Campbell MJ, Kejariwal A, Mi H, Karlak B, Daverman R, Diemer K, Muruganujan A, Narechania A 2003. PANTHER: a library of protein families and subfamilies indexed by function. Genome Res 13: 2129-2141

Google Scholar: Author Only Title Only Author and Title

Tieman D, Bliss P, Mclntyre LM, Blandon-Ubeda A, Bies D, Odabasi AZ, Rodríguez GR, van der Knaap E, Taylor MG, Goulet C (2012) The chemical interactions underlying tomato flavor preferences. Current Biology 22: 1035-1039

Google Scholar: Author Only Title Only Author and Title

Tieman D, Zhu G, Resende MFR, Lin T, Nguyen C, Bies D, Rambla JL, Beltran KSO, Taylor M, Zhang B, Ikeda H, Liu Z, Fisher J, Zemach I, Monforte A, Zamir D, Granell A, Kirst M, Huang S, Klee H (2017) A chemical genetic roadmap to improved tomato flavor. Science 355: 391

Google Scholar: Author Only Title Only Author and Title

Townsley BT, Covington MF, Ichihashi Y, Zumstein K, Sinha NR (2015) BrAD-seq: Breath Adapter Directional sequencing: a streamlined, ultra-simple and fast library preparation protocol for strand specific mRNAlibrary construction. Front Plant Sci 6: 366 Google Scholar: Author Only Title Only Author and Title

Townsley BT, Sinha NR (2012) Anew development: evolving concepts in leaf ontogeny. Annual review of plant biology 63 Google Scholar: Author Only Title Only Author and Title

Van Dingenen J, De Milde L, Vermeersch M, Maleux K, De Rycke R, De Bruyne M, Storme V, Gonzalez N, Dhondt S, Inzé D (2016) Chloroplasts Are Central Players in Sugar-Induced Leaf Growth. Plant Physiology 171: 590-605

Google Scholar: Author Only Title Only Author and Title

Wang D, Seymour G (2017) Tomato Flavor: Lost and Found? Molecular Plant 10:782-784

Google Scholar: Author Only Title Only Author and Title

Wenzel CL, Hester Q, Mattsson J (2008) Identification of genes expressed in vascular tissues using NPAinduced vascular overgrowth in Arabidopsis. Plant Cell Physiol 49: 457-468

Google Scholar: Author Only Title Only Author and Title

Xiao H, Jiang N, Schaffner E, Stockinger EJ, van der Knaap E (2008) ARetrotransposon-Mediated Gene Duplication Underlies Morphological Variation of Tomato Fruit. Science 319: 1527

Google Scholar: Author Only Title Only Author and Title

Yamaguchi M, Goué N, Igarashi H, Ohtani M, Nakano Y, Mortimer JC, Nishikubo N, Kubo M, Katayama Y, Kakegawa K, Dupree P, Demura T (2010) VASCULAR-RELATED NAC-DOMAN6 and VASCULAR-RELATED NAC-DOMAN7 Effectively Induce Transdifferentiation into Xylem Vessel Elements under Control of an Induction System. Plant Physiology 153: 906-914 Google Scholar: Author Only Title Only Author and Title

Yifhar T, Pekker I, Peled D, Friedlander G, Pistunov A, Sabban M, Wachsman G, Avarez JP, Amsellem Z, Eshed Y (2012) Failure of the tomato trans-acting short interfering RNA program to regulate AUXIN RESPONSE FACTOR3 and ARF4 underlies the wiry leaf syndrome. The Plant Cell 24: 3575-3589

Google Scholar: Author Only Title Only Author and Title 
bioRxiv preprint doi: https://doi.org/10.1101/2021.03 01.433399; this version posted March 1, 2021. The copyright holder for this preprint (which was not certified by peer review) is the author/funder, who has granted bioRxiv a license to display the preprint in perpetuity. It is made

Young MD, Wakefield MJ, Smyth GK, Oshlack A(2012) goseq: Gene Ontology testing for RNA-seq datasets. R Bioconductor 8: 1-25 Google Scholar: Author Only Title Only Author and Title

Zhou J, Wang X, Lee J-Y, Lee J-Y (2013) Cell-to-cell movement of two interacting AT-hook factors in Arabidopsis root vascular tissue patterning. The Plant Cell 25: 187-201

Google Scholar: Author Only Title Only Author and Title

Zhu Y, Kang H, Xie Q, Wang Z, Yin S, Liu C (2011) Pattern of leaf vein density and climate relationship of Quercus variabilis populations remains unchanged with environmental changes, Trees 26:597-607

Google Scholar: Author Only Title Only Author and Title 